\title{
Effect of catalyst preparation and storage on chemical looping
}

\section{epoxidation of ethylene}

\author{
E.J. Marek ${ }^{1,2 *}$, E. García-Calvo Conde ${ }^{1}$, \\ ${ }^{1}$ Department of Engineering, University of Cambridge, Trumpington Street, CB2 1PZ, United Kingdom \\ ${ }^{2}$ Department of Chemical Engineering and Biotechnology, University of Cambridge, Philippa Fawcett \\ Drive, CB3 0AS, United Kingdom \\ *Corresponding author: ejm94@cam.ac.uk
}

\begin{abstract}
Chemical looping epoxidation (CLE) of ethylene to ethylene oxide (EO) presents an exciting alternative to the incumbent technology of direct epoxidation of ethylene with $\mathrm{O}_{2(\mathrm{~g})}$. In CLE, the reaction is still catalysed by Ag but oxygen is provided as $\mathrm{O}_{\text {lattice }}$ from a solid metal oxide, eliminating the need and limitations of using $\mathrm{O}_{2(\mathrm{~g})}$. Here, the influence of catalyst preparation in CLE is investigated. The $\mathrm{Ag}$ catalyst was impregnated on a solid oxide, $\mathrm{SrFeO}_{3}$, which was used as the donor of $\mathrm{O}_{\text {lattice }}$ in CLE. Temperature programmed reduction in $\mathrm{H}_{2}$ indicated that $\mathrm{O}$-species participating in CLE can be attributed to the removal of the first monolayer of oxygen in $\mathrm{SrFeO}_{3}$. By changing the temperature of calcination in $\mathrm{Ag}-\mathrm{SrFeO}_{3}$ preparation, the size of $\mathrm{Ag}$ particles was varied, resulting in a simultaneous increase of selectivity for EO (up to $60 \%$ ) and conversion of $\mathrm{C}_{2} \mathrm{H}_{4}$ (up to $10 \%$ ). Then, an assessment of the effects of impurities (carbonates, hydroxides), which deposit over time on the $\mathrm{Ag}-\mathrm{SrFeO}_{3}$ surface, was performed, showing that impurities deteriorate the catalyst performance in CLE. Finally, the doping of the $\mathrm{SrFeO}_{3}$ with $\mathrm{Ce}$ to the A-site of the perovskite was carried out, and a substantial improvement of the conversion of $\mathrm{C}_{2} \mathrm{H}_{4}$ was achieved, reaching $15 \%$, while maintaining the $60 \%$ selectivity for EO.
\end{abstract}

Keywords: epoxidation, chemical looping, silver, perovskite, ethylene oxide 


\section{Introduction}

Ethylene oxide (EO), $\mathrm{C}_{2} \mathrm{H}_{4} \mathrm{O}$, serves as an important chemical intermediate with a production totalling 26 Mte in 2016 [1]. Industrial applications of EO include polymerisation of ethylene glycols, synthesis of fine chemicals, detergents, polyesters, and others [2]. The established industrial process for the production of EO involves a heterogeneous reaction of gaseous $\mathrm{C}_{2} \mathrm{H}_{4}$ and $\mathrm{O}_{2}$, the latter often delivered as purified oxygen [3]. Since the patenting of the process for EO production by Shell in 1958, Ag catalysts supported on low-surface alumina $\left(\alpha-\mathrm{Al}_{2} \mathrm{O}_{3}\right)$ have been the preferred choice [2,4], applying the loading of $\mathrm{Ag}$ between 7 to $20 \mathrm{wt} \%$, with the resulting lifetime of $\mathrm{Ag}-\mathrm{Al}_{2} \mathrm{O}_{3}$ catalyst of two to five years [5].

The direct epoxidation of $\mathrm{C}_{2} \mathrm{H}_{4}$ with $\mathrm{O}_{2(\mathrm{~g})}$ catalysed by pure Ag particles has a selectivity of $\sim 50 \%$, which can be successfully boosted to $90 \%$ when halogen and alkali promoters are added to the gas feed or deposited on the catalyst surface [4]. The process is also optimised by applying pressures of 1030 bar and varying the temperatures between 200 and $300^{\circ} \mathrm{C}$; both are adjusted for the best performance when the activity of the catalyst decreases with time $[3,6]$. Because of decrease in selectivity for EO with conversion of $\mathrm{C}_{2} \mathrm{H}_{4}$, industrial reactors are operated under small conversion and residence times of $\sim 1$ second [3]. Running the process at low conversions is also safer as it requires the gas stream outside the flammability limits, and minimises the risk of an uncontrolled runaway reaction: the combustion of EO [6] 
A new process has been recently described, where epoxidation of ethylene is carried out using the chemical looping approach [7]. In there, oxygen to the reaction is donated by a metal oxide, which acts as an active bank of $\mathrm{O}_{\text {lattice, }}$, and is justifiably termed as an oxygen carrier. Chemical looping epoxidation (CLE) comprises two separate steps, schematically shown in Fig. 1. First, the epoxidation is carried out,

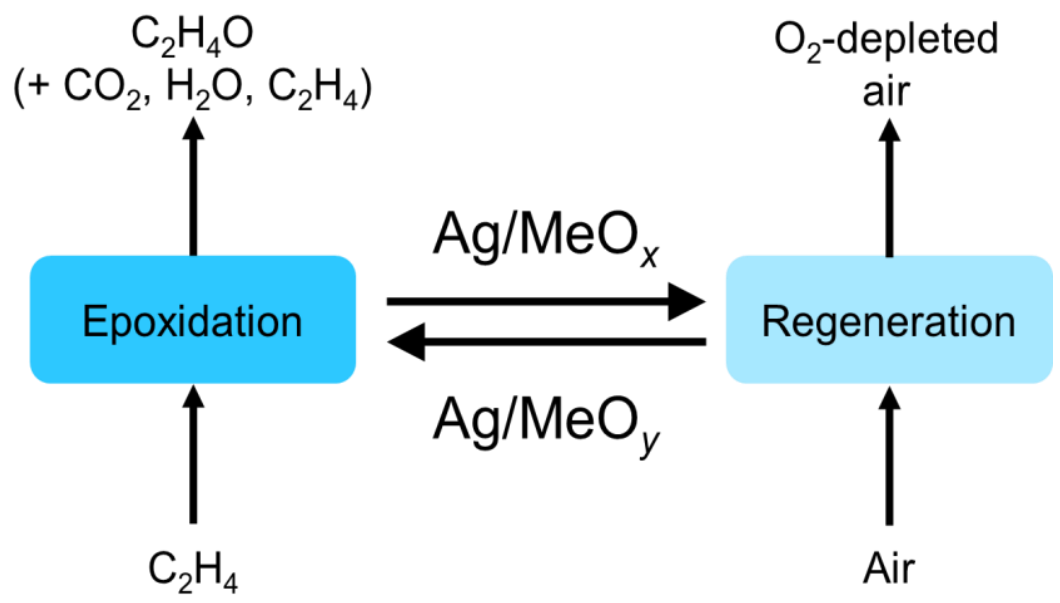

Fig. 1. Schematic representation of CLE. MeOx represents an oxygen carrier with a depleted reservoir of $O_{\text {lattice, }}$ $\mathrm{MeO}$ y represents the regenerated oxygen carrier.

and the oxygen carrier is successively depleted of $\mathrm{O}_{\text {lattice; }}$; second, the oxygen carrier is regenerated in air, which returns the solid bank of oxygen to the starting state $[7,8]$. Separating reactions into steps and using $\mathrm{O}_{\text {lattice }}$ in CLE or other selective reactions bring bountiful advantages over the incumbent processes, such as broader operating range and lower costs, to name just a few [9].

In the proof of concept, CLE was demonstrated using $\mathrm{Ag}$ as a catalyst, deposited on $\mathrm{SrFeO}_{3}$, which acted as an oxygen carrier (donor of $\mathrm{O}_{\text {lattice }}$ ) [7]. Chan et al. achieved promising selectivity for EO $~ 25 \%$ at $\sim 4 \%$ conversion of $\mathrm{C}_{2} \mathrm{H}_{4}$ but these quickly decreased with the duration of CLE. Clearly, the catalyst or oxygen carrier deactivated upon cycles of interspersed epoxidation and regeneration. The shortcoming was quickly overcome by Marek et al. [8]. By adding $5 \mathrm{~mol} \%$ of $\mathrm{CeO}_{2}$ to the bulk of $\mathrm{SrFeO}_{3}$, and keeping the same $\mathrm{Ag}$ catalyst, the authors achieved remarkable improvement in the performance, with $60 \%$ selectivity for $\mathrm{EO}$ at $10 \%$ conversion of $\mathrm{C}_{2} \mathrm{H} 4$, maintained in 15 cycles of CLE. The new oxygen carrier, comprising $\mathrm{CeO}_{2}$ in a mixture with $\mathrm{SrFeO}_{3}$ released oxygen faster and at lower temperatures than $\mathrm{SrFeO}_{3}$ alone. The work by Marek et al. [8] confirms that the properties of the oxygen carrier are paramount in CLE. Yet, another factors require further investigations, namely the 
presentation of the Ag catalyst and its interaction with the oxygen carrier. Furthermore, little work has been so far presented on the influence of carbonates, which can deposit both on $\mathrm{Ag}$ and $\mathrm{SrFeO}_{3}$ during material storage $[8,10]$.

Here, the influence of the preparation procedure and of the size of $\mathrm{Ag}$ particles on the performance of CLE was investigated. While keeping the same oxygen carrier, $\mathrm{SrFeO}_{3}$, and the same amount of $\mathrm{Ag}$ (15 wt\%), materials were varied by changing the calcination temperature in the Ag-impregnation step. Then, the resulting materials were investigated for chemical looping epoxidation. By varying the time from the calcination to the CLE experiments, samples with different levels of accumulation of surface impurities were investigated. Finally, for comparison with the solid mixture of $\mathrm{CeO}_{2}-\mathrm{SrFeO}_{3}$ studied by Marek et al. [8], a sample of $\mathrm{Sr}_{1-x} \mathrm{Ce}_{x} \mathrm{FeO}_{3}(x \leq 0.05)$ was synthesised and used as an oxygen carrier for CLE.

\section{Experimental}

\subsection{Material preparation}

\section{Oxygen carrier}

$\mathrm{SrFeO}_{3}$ was prepared by mixing $0.25 \mathrm{~mol}$ of $\mathrm{Fe}_{2} \mathrm{O}_{3}$ (Fisher Scientific, $\geq 95 \%$ ) and $0.5 \mathrm{~mol}$ of $\mathrm{SrCO}_{3}$ (Sigma Aldrich, $\geq 98 \%$ ). Ethanol (50 mL, 99.8\%, Fisher Scientific) was added to the powders, which were then mixed in a planetary ball mill (MTI, MSK-SFM-1) for $3 \mathrm{~h}$ at $25 \mathrm{~Hz}$. The resulting paste was dried in static air for $24 \mathrm{~h}$ at $50^{\circ} \mathrm{C}$, then crushed and sieved to $180-355 \mu \mathrm{m}$. The obtained particles were calcined in static air four times. Each time the sample was held at $1000^{\circ} \mathrm{C}$ for $3 \mathrm{~h}$, with ramping at $5^{\circ} \mathrm{C}$ $\min ^{-1}$. After calcination, the particles were sieved again to $180-355 \mu \mathrm{m}$. The stoichiometry of the perovskite obtained with this method is $\mathrm{SrFeO}_{2.82}$ [11]. For simplicity, the perovskite is denoted in this paper as $\mathrm{SrFeO}_{3}$.

$\mathrm{Sr}_{0.95} \mathrm{Ce}_{0.05} \mathrm{FeO}_{3}$ was prepared by combining $0.475 \mathrm{~mol}$ of $\mathrm{SrCO}_{3}, 0.25 \mathrm{~mol}$ of $\mathrm{Fe}_{2} \mathrm{O}_{3}$, and $0.025 \mathrm{~mol}$ of $\mathrm{CeO}_{2}$. The last oxide was obtained from cerium nitrate, $\mathrm{Ce}\left(\mathrm{NO}_{3}\right)_{3}$ (Sigma Aldrich, 99\%), by thermal decomposition, carried out for $4 \mathrm{~h}$ in a muffle furnace at $500^{\circ} \mathrm{C}$, heated with $1{ }^{\circ} \mathrm{C} \mathrm{min}^{-1}$. The mixture containing $\mathrm{Sr}, \mathrm{Ce}$, and $\mathrm{Fe}$ was further processed following the procedure of synthesising $\mathrm{SrFeO}_{3}$. After 
$12 \mathrm{~h}$ of calcination at $1000^{\circ} \mathrm{C}$, the obtained sample was analysed with $\mathrm{XRD}$, which revealed that $\mathrm{CeO}_{2}$ was present as a separate phase (see the Supporting Information, Fig. S1). The material was calcined again, first, for $10 \mathrm{~h}$, then, for additional $5 \mathrm{~h}$. The XRD detected less $\mathrm{CeO}_{2}$ with the prolonged calcination, indicating that the incorporation of Ce into the perovskite progressed slowly. In the final sample, only small peaks of $\mathrm{CeO}_{2}$ were observed, while the $\mathrm{SrFeO}_{3}$ peak at $46.95^{\circ}$ shifted to a lower value (see Fig. S2), indicating the expansion of the cell volume, expected when Ce substitutes Sr [12]. With the possibility of some $\mathrm{CeO}_{2}$ remaining next to the doped perovskite, the final sample is denoted as $\mathrm{Sr}_{1-x} \mathrm{Ce}_{x} \mathrm{FeO}_{3}(x \leq 0.05)$.

\section{Impregnation with $\mathrm{Ag}$}

$\mathrm{Ag}$ was dosed onto particles of the oxygen carriers - $\mathrm{SrFeO}_{3}$ and $\mathrm{Sr}_{1-x} \mathrm{Ce}_{x} \mathrm{FeO}_{3}$ - using incipient wetness impregnation. The pore volume of $\mathrm{SrFeO}_{3}$ had been determined previously [7] by adding water dropwise, until particles of $\mathrm{SrFeO}_{3}$ adhered, yielding $0.24 \mathrm{~mL} / \mathrm{g}$ of $\mathrm{SrFeO}_{3}$. The pore volume of $\mathrm{Sr}_{1-x} \mathrm{Ce}_{x} \mathrm{FeO}_{3}$ was assumed the same as $\mathrm{SrFeO}_{3}$. The silver solution was prepared by taking $1.3895 \mathrm{~g}$ of $\mathrm{AgNO}_{3}$ (Alfa Aesar, $\geq 99.9$ ) and dissolving it in $1 \mathrm{~mL}$ of deionised water. The solution was added dropwise to $5.0000 \mathrm{~g}$ of the oxygen carrier with agitation by a spatula. The sample was dried at $120^{\circ} \mathrm{C}$ for $12 \mathrm{~h}$ in static air and then calcined. Six samples of $\mathrm{Ag} / \mathrm{SrFeO}_{3}$ were obtained, each at a different temperature of calcination: $450^{\circ} \mathrm{C}, 500^{\circ} \mathrm{C}, 550^{\circ} \mathrm{C}, 600^{\circ} \mathrm{C}, 650^{\circ} \mathrm{C}$, and $700^{\circ} \mathrm{C}$. The ramp rate was always $5^{\circ} \mathrm{C} \min ^{-1}$, and the calcination lasted $5 \mathrm{~h}$. For the impregnation of $\mathrm{Sr}_{1-x} \mathrm{Ce}_{x} \mathrm{FeO}_{3}$, the calcination was carried out at $650^{\circ} \mathrm{C}$ only. For each sample, the impregnation resulted in $15 \mathrm{wt} \%$ of $\mathrm{Ag}$ loading. For differentiating between the samples, the description for each will be denoted using the temperature used in this calcination step.

\subsection{Material characterisation}

X-ray diffraction (XRD) measurements were collected with an Empyrean (PANalytical), using Cu$\mathrm{K} \alpha$ radiation (40 kV and $40 \mathrm{~mA}$ ). Diffraction patterns were obtained for $2 \theta$ ranging from $10^{\circ}$ to $80^{\circ}$, collected over 80 minutes. Rietveld refinement was performed with MAUD software [13], for confirming the presence of $\mathrm{SrFeO}_{3}$ (reference pattern from [14]), and $\mathrm{Ag}$ (reference pattern from [15]). 
Elemental analysis for the content of $\mathrm{Sr}, \mathrm{Fe}$, and $\mathrm{Ag}$ was performed with $\mathrm{Ag}$-impregnated samples, $\mathrm{SrFeO}_{3}$ and $\mathrm{Sr}_{1-x} \mathrm{Ce}_{x} \mathrm{FeO}_{3}$. Between 1 to $6 \mathrm{mg}$ of was dissolved by heating in nitric acid $(5 \mathrm{~mL})$ at $80^{\circ} \mathrm{C}$ for $2 \mathrm{~h}$. The obtained solutions were diluted forty-fold in water $(1 \mathrm{~mL}$ into $40 \mathrm{~mL})$ and analysed by Inductively Coupled Plasma - Optical Emission Spectrometry.

Thermogravimetric experiments (TGA) were undertaken in a TGA/DSC1 Mettler Toledo analyser with a horizontal reaction chamber. Oxygen release and uptake from materials were analysed in air/Ar mixture upon heating to $900^{\circ} \mathrm{C}$ (TPR); followed by cooling to $50^{\circ} \mathrm{C}$ (TPO), both with $10^{\circ} \mathrm{C} \mathrm{min}^{-1}$. TPR and TPO were carried out in two or three subsequent cycles to estimate the repeatability of the redox behaviour and possible accumulation of carbonates on the $\mathrm{Ag} / \mathrm{SrFeO}_{3}$ surface. In each experiment, the sample was placed in a $70 \mu \mathrm{L}$ alumina crucible and introduced to the TGA chamber, which was continuously purged with Ar (total flow of $100 \mathrm{~mL} \mathrm{~min}^{-1}$, NTP). An additional flow of 'reactive' gas $\left(50 \mathrm{~mL} \mathrm{~min}^{-1}, \mathrm{NTP}\right)$, here, always air, was introduced through a capillary above the crucible. All gases were BOC, $>99.998 \%$. Due to the dilution from Ar, which was continuously flowing through the TGA chamber, the actual concentration of the introduced 'reactive' gases was always $\sim 1 / 3$ of the nominal concentration from cylinders.

Low-temperature redox experiments in the TGA were performed isothermally, at $270^{\circ} \mathrm{C}$, by changing the type of the 'reactive' gas. A single CLE cycle, comprising 30 min reduction ('reactive' gas: 5.16 vol\% $\mathrm{C}_{2} \mathrm{H}_{4} / \mathrm{N}_{2}$ ), 1 min purge ('reactive' gas: $\mathrm{N}_{2}$ ), 80 min oxidation ('reactive' gas: air), was performed.

Scanning electron microscopy (SEM) images were taken using a Tescan Mira3 FEG-SEM. The accelerating voltage used was $3 \mathrm{kV}$ and the working distance between $3-6 \mathrm{~mm}$. The mean particle sizes were found by measuring the projected area of Ag particles (500 to 600 particles for each sample) detected with the "Analyze Particles" function in ImageJ and approved manually for analysis [16]. The determined area of $\mathrm{Ag}$ particles was used to calculate the diameter, assuming particles were spherical. Based on particle mean size from SEM, other parameters describing Ag presentation were evaluated: Ag dispersion, moles of surface Ag atoms, Ag surface area. The full description of the determined parameters is provided in the Supplementary Information, Section 2. Transmission Electron 
Microscopy (TEM) and Electron Energy Loss Spectroscopy (EELS) analysis were performed using TESCAN High Angle Dark Field Retractable STEM Detector. Zero-loss was acquired simultaneously with the core-losses allowing for Dual EELS. Energy Dispersive X-ray spectroscopy (EDX) was performed to analyse the elemental composition, either in specific points or by mapping selected regions.

The multipoint BET method was used to calculate the specific surface area (Nova 2200 Automatic Gas Sorption Analyser). Samples of $1 \mathrm{~cm}^{3}$ were degassed under vacuum for $6 \mathrm{~h}$ at $100^{\circ} \mathrm{C}$. The BET surface area measurement lasted $6 \mathrm{~h}$ and was carried out with liquid $\mathrm{N}_{2}$ at $-196^{\circ} \mathrm{C}$.

Temperature programmed reduction $\left(\mathrm{H}_{2}-\mathrm{TPR}\right)$ experiments were conducted in a Micromeritics Autochem II 2920 apparatus in conjunction with MKS Cirrus 2 mass spectrometer. In each experiment, $\sim 50 \mathrm{mg}$ of sample was heated up from 50 to $900^{\circ} \mathrm{C}$ with a $10^{\circ} \mathrm{C} \mathrm{min}^{-1}$ heating rate. During the heating, the sample was exposed to a continuous flow of $5 \mathrm{vol} \% \mathrm{H}_{2} / \mathrm{Ar}, 50 \mathrm{~mL}$ min- 1 (NTP). The off-gas was directed to a cold trap of isopropanol (cooled with liquid nitrogen) to remove water. Then, the composition of the dried gas was evaluated with a mass spectrometer, while the consumption of $\mathrm{H}_{2}$ was determined with a Thermal Conductivity Detector (TCD). To remove surface impurities before the $\mathrm{H}_{2}$ TPR experiments, all samples were calcined ex-situ in a muffle furnace for $5 \mathrm{~h}$ at $350^{\circ} \mathrm{C}$, in static air. The mass spectrometer collected signal from 1 to $40 \mathrm{amu}$, and the mass at 28 was assigned to $\mathrm{CO}_{2}$.

\subsection{Experiments for chemical looping epoxidation of ethylene}

Experiments were performed in a packed bed place in a $200 \mathrm{~mm}$ long quartz tube with the internal diameter of $8 \mathrm{~mm}$, and a sintered disk, supporting the bed, located $75 \mathrm{~mm}$ from the bottom. A schematic representation of the experimental setup is shown in Fig. S3 in the Supplementary Information. Bed was created with three layers: with $2 \mathrm{~g}$ of active material with Ag catalyst, as a middle layer, positioned between two layers of $\mathrm{Al}_{2} \mathrm{O}_{3}(2 \mathrm{~g}$ each, 355-425 $\mu \mathrm{m})$. The quartz tube was wrapped with a heating tape, set to $270^{\circ} \mathrm{C}$. The temperature inside the reactor was measured with a thermocouple (K type) inserted in the middle of the bed of the active material. The temperature measurement was used for controlling the heating of the heating tape. 
The gases used in the experiments were 5.16 vol\% $\mathrm{C}_{2} \mathrm{H}_{4}$ in $\mathrm{N}_{2}$ (for the epoxidation step), $\mathrm{N}_{2}$ (for purge), and air (for reoxidation). Gas flows of $200 \mathrm{~mL} \mathrm{~min}^{-1}$ (NTP) were set with rotameters and measured with an electronic flowmeter (ADM). The residence time for gases in the bed of catalyst was $0.29 \mathrm{~s}$, while GHSV based on the catalyst volume was $6250 \mathrm{~h}^{-1}$. A cycling experiment was performed by switching gases with solenoid valves according to a time-based programme. A single CLE experiment included ten cycles, each comprising four stages: i) purge with $\mathrm{N}_{2}$ for 2 min, ii) epoxidation with $\mathrm{C}_{2} \mathrm{H}_{4}$ for $1.5 \mathrm{~min}$, iii) purge with $\mathrm{N}_{2}$ for $2 \mathrm{~min}$, iv) regeneration with air for $15 \mathrm{~min}$.

The off-gas from the reactor was directed to a Fourier Transform Infrared analyser (FTIR, MKS Instruments, Multigas 2030) with a gas cell of $5.11 \mathrm{~m}$, which was heated to $150^{\circ} \mathrm{C}$. The analyser was equipped with a $\mathrm{HgCdTe}$ detector, cooled with liquid $\mathrm{N}_{2}$. Before each CLE experiment, the detector was allowed to cool for $2 \mathrm{~h}$ while the packed bed was kept at $270^{\circ} \mathrm{C}$ and purged with air. A single FTIR measurement was performed every $1.87 \mathrm{~s}$, averaging $8 \mathrm{scans}$ of the band $800-4600 \mathrm{~cm}^{-1}$, at a resolution of $0.5 \mathrm{~cm}^{-1}$. The FTIR spectra were analysed for $\mathrm{C}_{2} \mathrm{H}_{4}, \mathrm{EO}, \mathrm{CO}, \mathrm{CO}_{2}$, and $\mathrm{H}_{2} \mathrm{O}$ using MKS' software (MG2000).

Parameters calculated from the CLE experiments include the flowrate at the reactor outlet, average and instantaneous selectivity for EO and conversion of $\mathrm{C}_{2} \mathrm{H}_{4}$, turnover frequencies (TOF) for both species, and carbon balance. The collected FTIR signal was deconvoluted using a first-order CSTRmodel. The description of calculated parameters and the effect of deconvolution are shown in the Supplementary Information (sections 4 and 5). The measurement of $\mathrm{H}_{2} \mathrm{O}$ was not used in further analysis. Water was accounted for when estimating parameters of CLE, but the $\mathrm{H}_{2} \mathrm{O}$ concentration was evaluated from the stoichiometry of two combustion reactions: $0.5 \mathrm{C}_{2} \mathrm{H}_{4}+3 / 2 \mathrm{O}_{2} \rightarrow \mathrm{CO}_{2}+\mathrm{H}_{2} \mathrm{O}$, and $0.5 \mathrm{C}_{2} \mathrm{H}_{4}+\mathrm{O}_{2} \rightarrow \mathrm{CO}+\mathrm{H}_{2} \mathrm{O}$, i.e., $1 \mathrm{~mol}$ of generated $\mathrm{CO}_{2}$ or $\mathrm{CO}$ implied that $1 \mathrm{~mol}$ of $\mathrm{H}_{2} \mathrm{O}$ was also generated, and that 1.5 or $1 \mathrm{~mol}$ of $\mathrm{O}_{2}$ was consumed. 
The reproducibility of CLE was analysed with two $\mathrm{Ag} / \mathrm{SrFeO}_{3}$ samples prepared from different $\mathrm{SrFeO}_{3}$ batches. Samples of $\mathrm{SrFeO}_{3}$ were impregnated with $\mathrm{AgNO}_{3}$ with calcination at $650^{\circ} \mathrm{C}$,

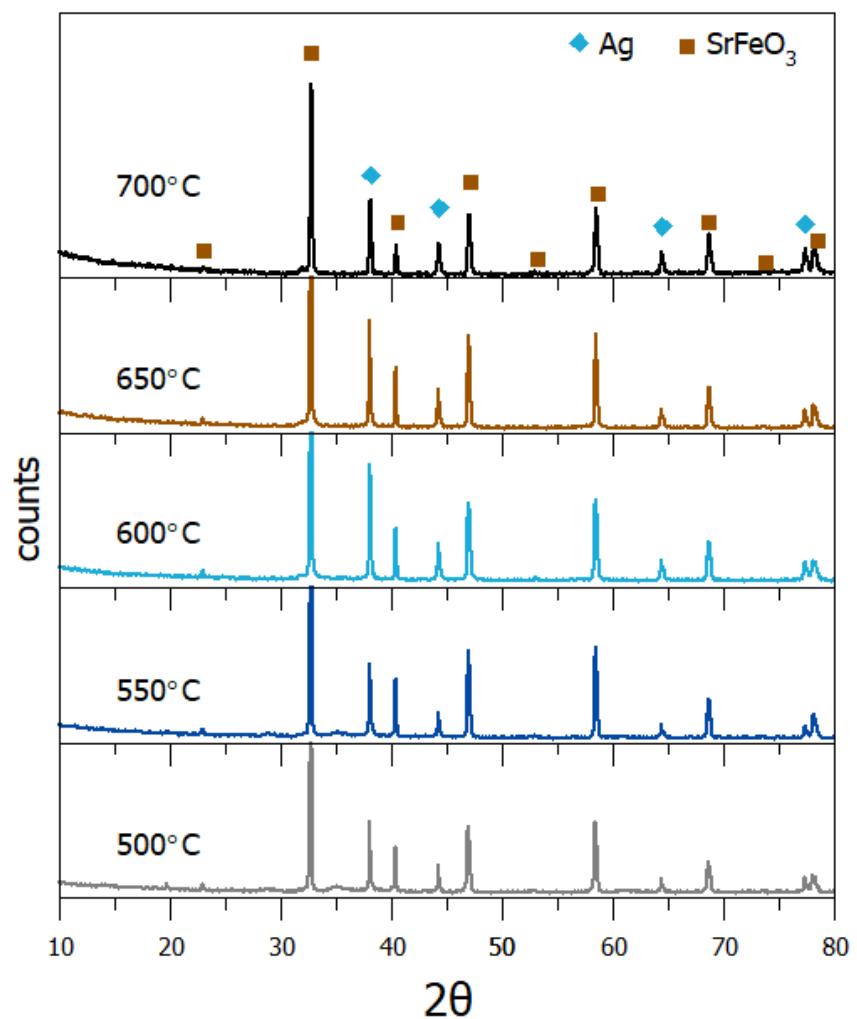

Fig. 2. XRD results of $\mathrm{SrFeO}_{3}$ impregnated with $15 \mathrm{wt} \% \mathrm{Ag}$ and calcined at various temperatures, between 500 and $700^{\circ} \mathrm{C}$.

performed on different days. Conversion of $\mathrm{C}_{2} \mathrm{H}_{4}$ and selectivity for $\mathrm{EO}$ differed to $3 \%$ (Supporting Information, Fig. S5). A CLE experiment with bare $\mathrm{SrFeO}_{3}$ was also performed, but no EO was detected. The only product in the off-gas was $\mathrm{CO}_{2}$, with an averaged concentration of $500 \mathrm{ppm}$. 


\section{Results}

\subsection{Materials characterisation}

The composition of the prepared samples was analysed with XRD and the results confirmed the presence of face-centred cubic $\mathrm{Ag}$, and $\mathrm{SrFeO}_{3}$ perovskite, as shown in Fig. 2 for 15 wt $\% \mathrm{Ag} / \mathrm{SrFeO}$. Small amounts of impurities of $\mathrm{Sr}_{3} \mathrm{Fe}_{2} \mathrm{O}_{7}$ were also present, although in the amount lower than the measurement error, accounting for less than $5 \mathrm{wt} \%$. Similar results were observed previously [8] when using the same experimental techniques. The result of doping of the perovskite with $\mathrm{Ce}$ is presented in the Supplementary Information, Figs. S1 and S2, confirming that Ce was incorporated into the perovskite resulting in $\mathrm{Sr}_{1-x} \mathrm{Ce}_{x} \mathrm{FeO}_{3}$.

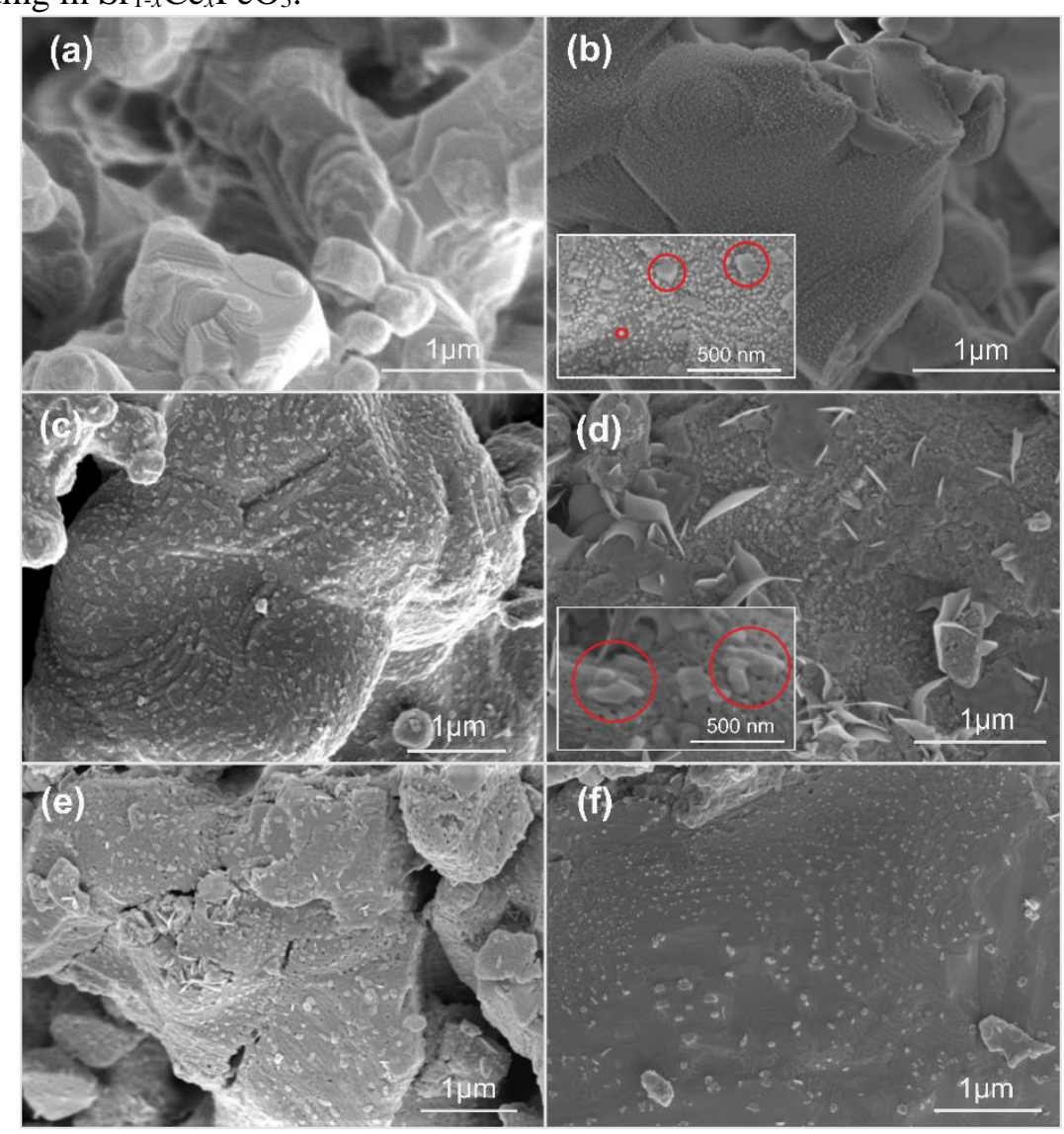

Fig. 3. SEM images of (a) bare $\mathrm{SrFeO}_{3}$, and $15 \mathrm{wt} \% \mathrm{Ag} / \mathrm{SrFeO}_{3}$ calcined at (b) $500^{\circ} \mathrm{C}$, (c) $550^{\circ} \mathrm{C}$, (d) $600^{\circ} \mathrm{C}$, (e) $650^{\circ} \mathrm{C},(f) 700^{\circ} \mathrm{C}$. Inserts show Ag particles (red circles) in more detail. Working distance within 3-5 mm.

Typical SEM images of the surface of $15 \mathrm{wt} \% \mathrm{Ag} / \mathrm{SrFeO}_{3}$ particles calcined at various temperatures are presented in Fig. 3. Clearly, the samples differed because of the changing morphology of the Ag particles. At the lower calcination temperature, $\mathrm{Ag}$ was present in the form of small, spherical particles 
(Fig. 3a), which became larger when the temperature in the thermal treatment was increased (Fig. 3b). At higher calcination temperatures, $600^{\circ} \mathrm{C}$ and $650^{\circ} \mathrm{C}$, new forms of $\mathrm{Ag}$ morphologies were observed (Figs. 3c and d), such as dendritic or worm-like shapes. The agglomerating behaviour of Ag upon thermal or chemical treatment is well known [17], and results from Ag particle migration, atom migration (Ostwald ripening), sublimation of nanoparticles [18,19]. In epoxidation of $\mathrm{C}_{2} \mathrm{H}_{4}$ with $\mathrm{O}_{2(\mathrm{~g})}$, agglomeration of Ag was linked with higher selectivity for EO [20], but also, along Ag poisoning, was found responsible for catalyst deactivation [21].

The mean size of the Ag particles in each sample of $15 \mathrm{wt} \% \mathrm{Ag} / \mathrm{SrFeO}_{3}$ was evaluated using SEM (Table 1). In the calculations for mean diameter, spherical particles were assumed, which is correct only for small particles restricted by high surface tension [22], while, for other shapes, represents the equivalent diameter rather than the characteristic length. Nevertheless, the results from SEM gave the same trend as the results from XRD (Table S1), namely, the average size of $\mathrm{Ag}$ deposited on $\mathrm{SrFeO}_{3}$ increased with the calcination temperature except for the sample calcined at $700^{\circ} \mathrm{C}$. The smaller size at $700^{\circ} \mathrm{C}$ resulted likely from the sublimation of $\mathrm{Ag}$ particles [23]. Elemental analysis confirms that the Ag content was significantly smaller in the sample calcined at the highest temperature $(16.5 \mathrm{w} / \mathrm{w} \%$, metal basis for the $700^{\circ} \mathrm{C}$ sample $v s 17.8 \pm 0.8 \mathrm{w} / \mathrm{w} \%$ of the average loading in all samples). The smaller size could have also resulted from the migration of $\mathrm{Ag}$ into $\mathrm{SrFeO}_{3}$ pores [23-25], resulting in a dendritic Ag network. Here, the migration might have been induced by $\mathrm{O}_{2(\mathrm{~g})}$ release and uptake from $\mathrm{SrFeO}_{3}$, that would be significant at $700^{\circ} \mathrm{C}$.

The movement of $\mathrm{Ag}$ at lower temperatures, such as $270^{\circ} \mathrm{C}$ used in CLE, is much slower, and, despite the chemical reactions, the size of Ag did not change (Table 1). Indeed, the noticeable effect from agglomeration can take years [18]. Thus, the proposed thermal treatment provides an opportunity to optimise the distribution of Ag on oxygen carriers in CLE. The BET surface area did not change significantly with the calcination temperature, although, as shown in Fig. 3, the deposited Ag particles blocked pores, and access to the bulk of $\mathrm{SrFeO}_{3}$. 
Table 1. Characterisation of $15 \mathrm{wt} \% \mathrm{Ag} / \mathrm{SrFeO}_{3}$ samples calcined at varius temperatures.

\begin{tabular}{ccccccc}
\hline Calcination & Ag & BET & Mean size of Ag, SEM, & Ag & Ag & Moles of \\
temperature & content & Surface & $d_{4,3}$ & dispersio & surface & surface Ag, \\
& $($ metal & area $S_{\text {a }}$ & & n SEM, & area, $S_{a}$ & $n_{s}$ \\
& basis $)$ & & & $D$ & &
\end{tabular}

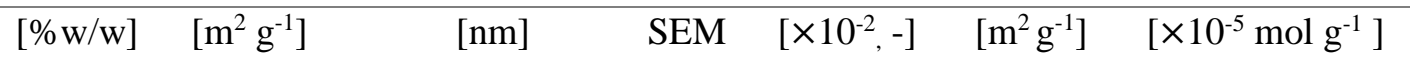

$\begin{array}{llllllll}\mathbf{5 0 0}^{\circ} \mathbf{C} & 17.7 & 1.30 & 69 & 4 & 1.99 & 1.45 & 2.75\end{array}$

(after CLE 67)

\begin{tabular}{lccccccc}
\hline $\mathbf{5 5 0}^{\circ} \mathbf{C}$ & 18.6 & 1.48 & 71 & 1 & 1.87 & 1.37 & 2.60 \\
& & & & & & & \\
$\mathbf{6 0 0}^{\circ} \mathbf{C}$ & 18.2 & 1.27 & 97 & 2 & 1.40 & 0.88 & 1.96 \\
& & & & & & & \\
\hline $\mathbf{6 5 0}^{\circ} \mathbf{C}$ & 18.0 & 1.65 & 170 & 1 & 1.18 & 0.50 & 1.63
\end{tabular}

(after CLE 164)

\begin{tabular}{llllllll}
\hline $\mathbf{7 0 0}^{\circ} \mathbf{C}$ & 16.5 & NA & 76 & 1 & $1.88^{*}$ & $1.38^{*}$ & $2.62^{*}$
\end{tabular}

* calculated for $15 \mathrm{wt} \%$ of $\mathrm{Ag}$ in the sample

The mass changes during a single CLE-cycle experiment at $270^{\circ} \mathrm{C}$ in the TGA are shown in Fig. 4. Common to all samples, the rate of reduction of the oxygen carrier $\left(\mathrm{SrFeO}_{3}\right)$ in $\mathrm{C}_{2} \mathrm{H}_{4}$ was much faster than the rate of reoxidation in air. The samples that were calcined at lower temperatures were less active,

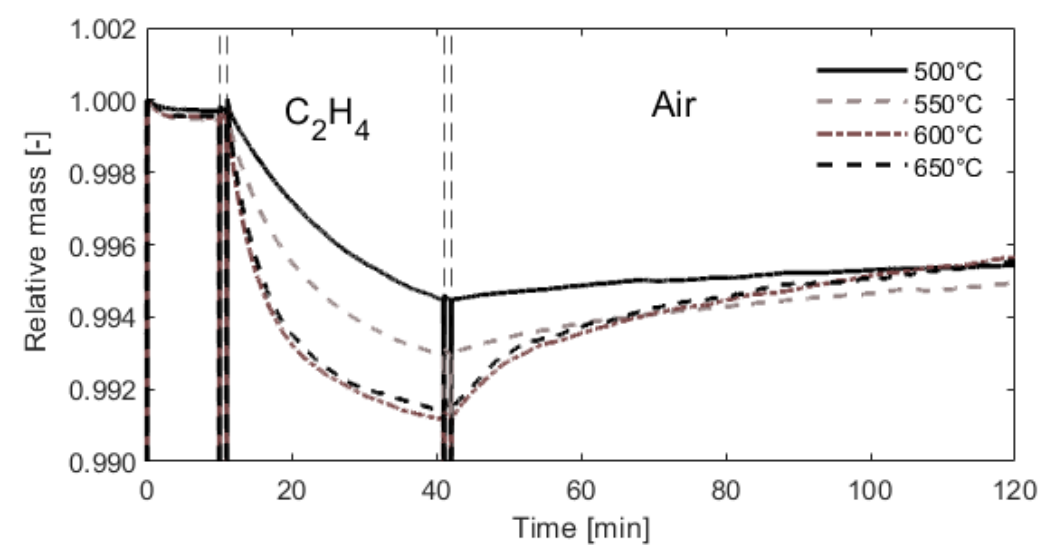

Fig. 4. Mass change of $15 \mathrm{wt} \% \mathrm{Ag} / \mathrm{SrFeO}_{3}$ samples during reduction in $\mathrm{C}_{2} \mathrm{H}_{4}$ (as a 'reactive' gas, $30 \mathrm{~min}$ ) and reoxidation in air (as a 'reactive' gas, $80 \mathrm{~min}$ ), measured in TGA. Isothermal experiment at $270^{\circ} \mathrm{C}$. The samples differed by the temperature of calcination $\left(500-650^{\circ} \mathrm{C}\right.$ ) applied when impregnating $\mathrm{Ag}$ on $\mathrm{SrFeO}_{3}$. 
with lower rates of reduction and reoxidation than the samples thermally treated at higher temperatures. As all samples were of the same chemical composition, the observed difference in performance can be attributed mainly to the temperature of calcination, and the resulting difference in $\mathrm{Ag}$ size and $\mathrm{Ag}$ $\mathrm{SrFeO}_{3}$ interface. The results in Fig. 4 provide evidence that $\mathrm{Ag}$ was catalytically active not only in epoxidation but also during regeneration, which likely comes from silver's high affinity to oxygen and its positive influence on $\mathrm{SrFeO}_{3}$ ionic and electronic conductivity [26]. The same enhanced behaviour was observed in TPR-TPO in air, where the addition of $\mathrm{Ag}$ to $\mathrm{SrFeO}_{3}$ resulted in faster release of $\mathrm{O}_{2(\mathrm{~g})}$ when compared to bare $\mathrm{SrFeO}_{3}$ (Fig. S6). The catalytic influence of a noble metal on redox of perovskite was noted by Beppu et al. [27], when the impregnation of 1 wt $\%$ of $\mathrm{Pd}$ onto $\mathrm{Sr}_{3} \mathrm{Fe}_{2} \mathrm{O}_{7}$ significantly enhanced its oxygen release and storage. The results in Fig. 4 indicate that the morphology of the catalytically acting metal matters, and the observation might be of interest for other applications, such as oxygen separation for producing purified $\mathrm{O}_{2(\mathrm{~g})}$.

Figure 5 presents EELS spectra collected for Fe $\mathrm{L}_{3}\left(2 \mathrm{p}_{3 / 2} \rightarrow 3 \mathrm{~d}\right)$ and $\mathrm{L}_{2}\left(2 \mathrm{p}_{1 / 2} \rightarrow 3 \mathrm{~d}\right)$ edge of two samples with clearly different $\mathrm{Ag}$ morphologies, one calcined at $500^{\circ} \mathrm{C}$ and the other at $650^{\circ} \mathrm{C}$. The $\mathrm{Fe}$ $\mathrm{L}_{3}$ and $\mathrm{L}_{2}$ features depend on the local valence state of $\mathrm{Fe}$, namely, for $\mathrm{Fe}^{4+}$ and $\mathrm{Fe}^{3+}$ cations, the position of both features slightly shifts [28], and so is the ratio of their intensities $\left(I_{L 3} / I_{L 2}\right)$ [29]. The results in Fig. 5 show that the Fe electronic state in both samples differed even though the spectra were collected at room temperature, so at the same $\delta$. Another explanation involves the interaction between $\mathrm{Ag}$ and $\mathrm{Fe}$, which imposes a charge transfer towards Ag via the ligand effect [30]. Expecting a lower $I_{L 3} / I_{L 2}$ ratio for samples with a higher content of $\mathrm{Fe}^{4+}[29]$, the results for sample calcined at $650^{\circ} \mathrm{C}$ indicate a more

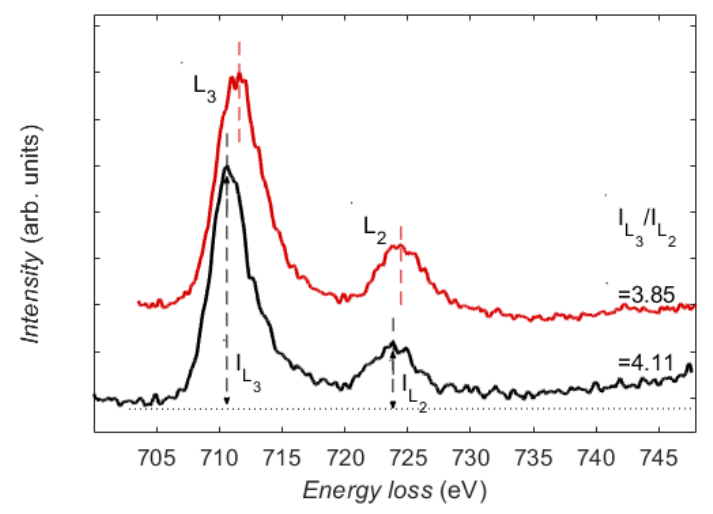

Fig. 5. Fe L L2,3 edge EELS obtained from $\mathrm{Ag}-\mathrm{SrFeO}_{3}$ calcined at $500^{\circ} \mathrm{C}$ (black) and $\mathrm{Ag}$-SrFeO 3 calcined at $650^{\circ} \mathrm{C}$ (red). 
pronounced charge transfer towards $\mathrm{Ag}$ then for the sample calcined at $500^{\circ} \mathrm{C}$. While chemically, both samples were identical, the only difference between them was the size of Ag particles and the applied thermal treatment.

When exposed to air, the surface of $\mathrm{Ag}$ and $\mathrm{SrFeO}_{3}$ tend to cover with carbonates and hydroxides [10,11], and the amount of surface impurities increases with the time of sample storage [12]. Neither was noticed in XRD, but $\mathrm{CO}_{2}$ and water were observed in the off-gas from the packed bed reactor, when heating the $\mathrm{Ag} / \mathrm{SrFeO}_{3}$ sample prior to experiments (Fig. S11). The impurities were noticed with TEM in the sample calcined at the lower temperature, $500^{\circ} \mathrm{C}$, present as an amorphous layer that trapped $\mathrm{Ag}$ particles, or as a crystallite Sr-O-compound, as presented in Fig. 6 a) and b). The distances between lattice planes, in Fig. 6 b) align with $d$ between (220), (020), (021) for $\operatorname{Sr}(\mathrm{OH})_{2},(210)$ and (200) for $\mathrm{SrCO}_{3}$, but does not agree with distances observed for SrO. In both Fig. 6 a) and b), the composition was checked with EDX (Section 11 in the Supplementary Information), confirming that the species at the surfaces contain $\mathrm{Sr}$ and $\mathrm{O}$ (but no $\mathrm{Ag}$ or $\mathrm{Fe}$ ). The amorphous form of the carbonate and hydroxide is possible [31,32], although neither is thermally stable. In contrast, the surface of the sample calcined at $650^{\circ} \mathrm{C}$, Fig. $6 \mathrm{c}$ ) and d), was free of impurities. In result, Ag particles were well-positioned at the surface of $\mathrm{SrFeO}_{3}$.

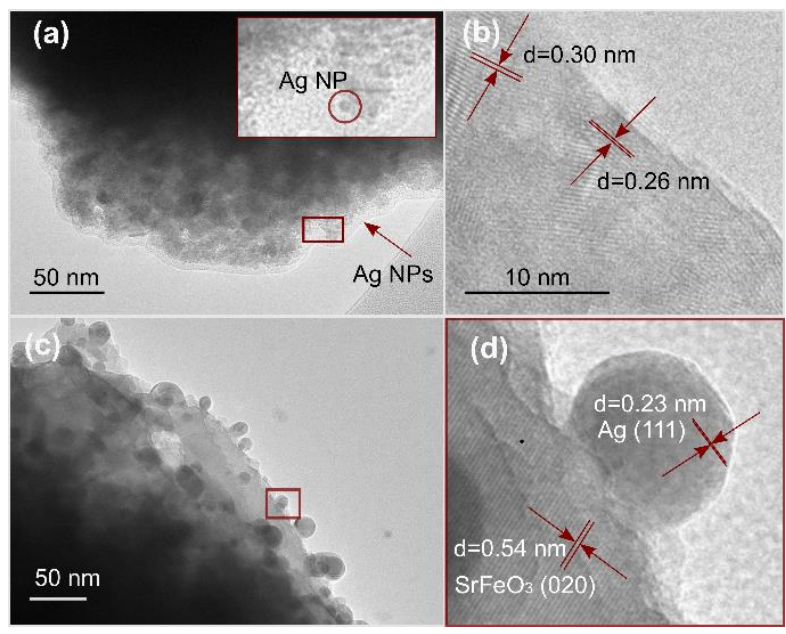

Fig. 6. TEM images of $\mathrm{Ag}-\mathrm{SrFeO}_{3}$ (a) calcined at $500^{\circ} \mathrm{C}$ (stored $>60$ days), $\mathrm{Ag}$ nanoparticles are trapped in an amorphous layer, (b) fringes of $\mathrm{Sr}$ and $\mathrm{O}$ rich region at the surface of the same sample as in a), (c) calcined at $650^{\circ} \mathrm{C}$ (stored $>60$ days), (d) magnification of the region in c) marked with red rectangle: Ag particle deposited on $\mathrm{SrFeO}_{3}$. 
The influence of impurities on the oxygen release and uptake of stored ( $>60$ days) $\mathrm{Ag} / \mathrm{SrFeO}_{3}$ was investigated in the TGA, with TPR-TPO cycles, performed in air, with results presented in Fig. 7. Upon heating, all samples showed mass loss that was not regained in cooling, confirming the presence of impurities. However, the introduction of $\mathrm{Ag}$ to $\mathrm{SrFeO}_{3}$, and the calcination temperature affected the deposition of impurities. In the samples calcined at $500^{\circ} \mathrm{C}$ and $550^{\circ} \mathrm{C}$, the concentration of impurities was larger than in bare $\mathrm{SrFeO}_{3}$. For the rest of the samples, the impurities amounted to $\sim 1 \mathrm{wt} \%$ of the starting mass. Interestingly, the impurities in these samples were released already at low temperatures $\left(<270^{\circ} \mathrm{C}\right)$, while the mass loss in samples calcined at 500 and $550^{\circ} \mathrm{C}$ started only above $400^{\circ} \mathrm{C}$. Clearly, the chemical character and the strength of the surface bonding differed between the samples. The storage of samples beyond 110 days did not influence the mass loss in the TGA (Fig. S8), indicating that the $\mathrm{Ag} / \mathrm{SrFeO}_{3}$ surface saturated with the impurities.



Fig. 7. Mass change profiles from TPR-TPO for bare $\mathrm{SrFeO}_{3}$ and samples of $15 \mathrm{wt} \% \mathrm{Ag} / \mathrm{SrFeO} \mathrm{O}_{3}$ calcined at various temperatures. Two temperature programmed cycles: each from 50 to $900^{\circ} \mathrm{C}(\mathrm{TPR})$ and 900 to $50^{\circ} \mathrm{C}(\mathrm{TPO})$, both steps in air (effective $\mathrm{p} \mathrm{O}_{2}=0.07$ bar), with cooling and heating rate of $10^{\circ} \mathrm{C} / \mathrm{min}$. All samples were stored $>60$ days from the last thermal treatment. TPR in cycle 1 accounts for the removal of impurities (carbonates and hydroxides) and release of oxygen, while the TPR in cycle 2 accounts for oxygen release only. See Fig. S7 for mass change vs temperature.

During the reduction in $\mathrm{H}_{2}$-TPR, presented in Fig. 8, each $\mathrm{Ag}-\mathrm{SrFeO}_{3}$ sample showed several reduction steps. Reduction of $\operatorname{Ag}_{x} \mathrm{O}_{y}$ and oxygen-adsorbed species on $\mathrm{Ag}$ takes place below $120^{\circ} \mathrm{C}$ [33], so was not seen in the $\mathrm{H}_{2}$-TPR experiments here. The bulk-dissolved oxygen reduces at higher temperatures, even up to $460^{\circ} \mathrm{C}$, but it's contribution in the TPR profiles is lower than Ag-oxides [34], thus, here, negligible. 


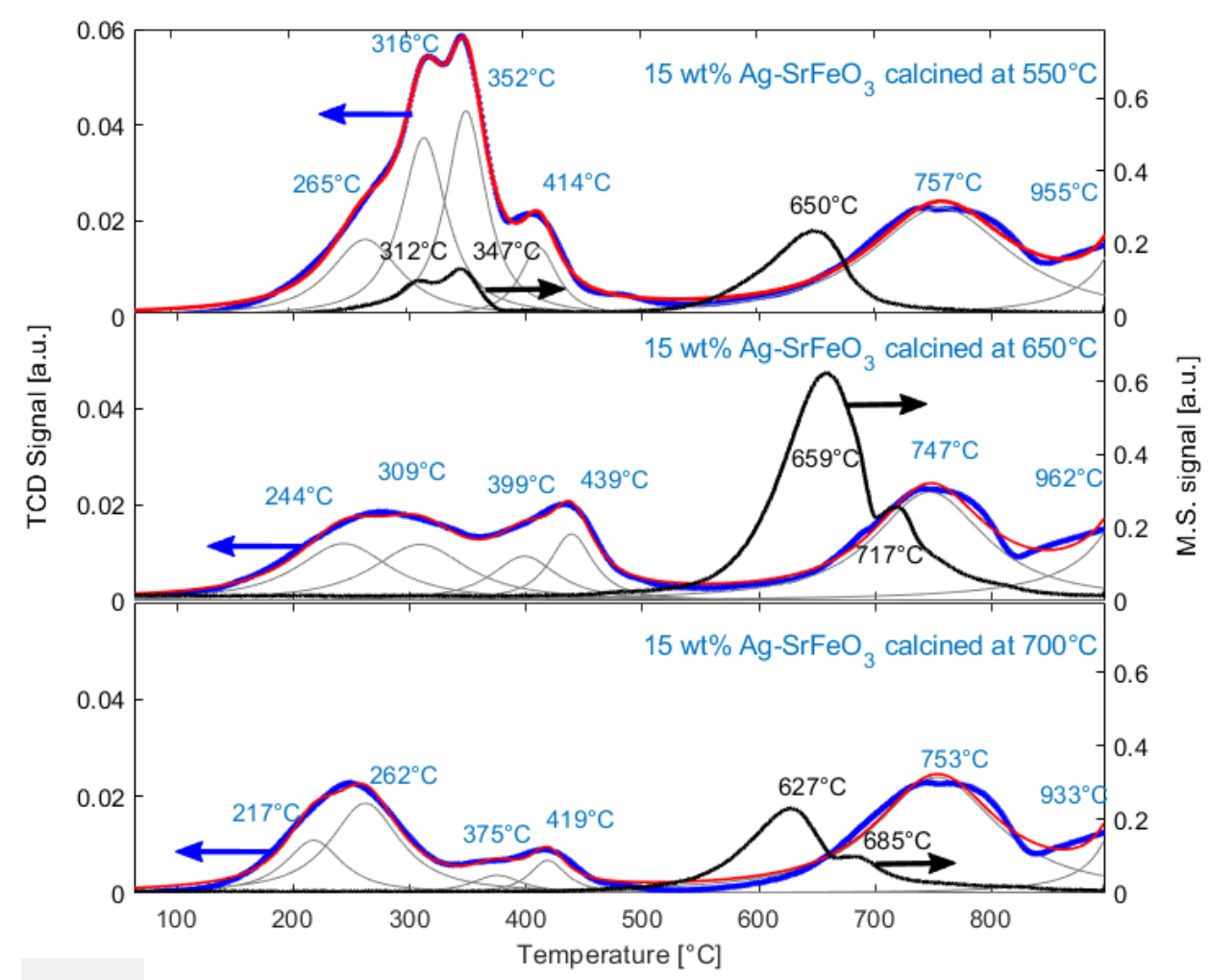

Fig. 8. $\mathrm{H}_{2}-\mathrm{TPR}-\mathrm{MS}$ of $15 \mathrm{wt} \% \mathrm{Ag}-\mathrm{SrFeO} \mathrm{O}_{3}$ calcined at 550,650 or $700^{\circ} \mathrm{C}$. Blue dotted lines indicate the $\mathrm{H}_{2}$ signal from the TCD analyser, red - the modelled signal, grey-fitted peaks. Measurement from the mass spectroscopy (right $Y$-axis) is presented with the black line and indicates $\mathrm{CO}_{2}$ release.

The results in Fig. 8 were modelled with four peaks in $100-500^{\circ} \mathrm{C}$ range and two high-temperature peaks. The first peak, observed at $217-265^{\circ} \mathrm{C}$, was assigned to the removal of the reactive oxygen species, which are weakly bound to $\mathrm{SrFeO}_{3}$ surface (first monolayer of the oxide [35]) because phase reduction of $\mathrm{SrFeO}_{3}$ in $\mathrm{H}_{2}$ does not occur in this temperature region $[11,35]$. The three peaks observed between 262 and $500^{\circ} \mathrm{C}$ were attributed to the reduction of $\mathrm{Fe}^{4+}$ to $\mathrm{Fe}^{3+}$, representing perovskite brownmillerite transformation [35]. The two final peaks $>700^{\circ} \mathrm{C}$ correspond to the step-wise reduction of $\mathrm{Fe}^{3+}$ to $\mathrm{Fe}^{2+}$, and further reduction ${ }^{+}$to the metallic iron [36]. The shift of the reduction temperature with increasing temperature of calcination corroborates with conclusions about the increasing interaction between $\mathrm{SrFeO}_{3}$ and $\mathrm{Ag}$, and the electronic modifications at the $\mathrm{Ag}-\mathrm{SrFeO}_{3}$ surface. This indicates that the oxidising potential increased with the calcination temperature, and for the sample calcined at $700^{\circ} \mathrm{C}$, its chemical potential in the CL-temperature range $\left(270^{\circ} \mathrm{C}\right)$ was high enough to promote complete combustion [9]. 
The results from the mass spectroscopy (Fig. 8) showed that during the $\mathrm{H}_{2}$-TPR, each sample produced $\mathrm{CO}_{2}$, with two peaks observed between 600 and $700^{\circ} \mathrm{C}$. Sample calcined at $550^{\circ} \mathrm{C}$ additionally released $\mathrm{CO}_{2}$ at a lower temperature $\left(<350^{\circ}\right)$, which confirms that $\mathrm{CO}_{2}$ in these samples was bounded strongly to the surface and could obstruct epoxidation. At low temperature, the released $\mathrm{CO}_{2}$ reacted with $\mathrm{H}_{2}$ through the water-gas shift reaction, increasing the consumption of $\mathrm{H}_{2}$ within peaks 2 and 3 for the sample calcined at $550^{\circ} \mathrm{C}$ (Table 2).

Table 2. $\mathrm{H}_{2}$ consumption in the $\mathrm{H}_{2}-\mathrm{TPR}$. Peaks are presented in Fig. 8.

\begin{tabular}{|c|c|c|c|c|c|c|}
\hline Sample & $550^{\circ} \mathrm{C} 15 \mathrm{wt}{ }^{\circ}$ & $\mathrm{Ag} / \mathrm{SrFeO}_{3}$ & $550^{\circ} \mathrm{C} 15 w t \%$ & $/ \mathrm{SrFeO}_{3}$ & $550^{\circ} \mathrm{C} 15 \mathrm{wt} \%$ & $\mathrm{Ag} / \mathrm{SrFeO}_{3}$ \\
\hline Peak No & $\begin{array}{c}\text { Temperature } \\
{\left[{ }^{\circ} \mathrm{C}\right]}\end{array}$ & $\begin{array}{c}\mathrm{H}_{2} \\
\text { consumed } \\
{[\mathrm{mmol} / \mathrm{g}]}\end{array}$ & $\begin{array}{l}\text { Temperature } \\
{\left[{ }^{\circ} \mathrm{C}\right]}\end{array}$ & $\begin{array}{c}\mathrm{H}_{2} \\
\text { consumed } \\
{[\mathrm{mmol} / \mathrm{g}]}\end{array}$ & $\begin{array}{c}\text { Temperature } \\
{\left[{ }^{\circ} \mathrm{C}\right]}\end{array}$ & $\begin{array}{c}\mathrm{H}_{2} \\
\text { consumed } \\
{[\mathrm{mmol} / \mathrm{g}]}\end{array}$ \\
\hline 1 & 265 & 0.50 & 243 & 0.58 & 217 & 0.34 \\
\hline 2 & 316 & 0.78 & 309 & 0.59 & 262 & 0.71 \\
\hline 3 & 352 & 0.79 & 399 & 0.33 & 375 & 0.11 \\
\hline 4 & 414 & 0.25 & 439 & 0.34 & 419 & 0.14 \\
\hline 5 & 757 & 1.26 & 747 & 1.25 & 753 & 1.46 \\
\hline 6 & 956 & 0.20 & 962 & 0.34 & 934 & 0.16 \\
\hline Total & - & 3.79 & - & 3.42 & - & 2.92 \\
\hline
\end{tabular}




\subsection{Chemical looping epoxidation}

\section{Effect of calcination temperature on catalyst performance}

The typical outcome of a chemical looping experiment carried out in the packed bed reactor is shown in Fig. 9. Each experiment consisted of 10 redox cycles, with gas introduced as indicated by the colour map. Peaks in the mole fractions of the two main products of interest, $\mathrm{EO}$ and $\mathrm{CO}_{2}$, indicate when the reduction in $\mathrm{C}_{2} \mathrm{H}_{4}$ took place. No coking was observed for any catalyst.

Figure 10 shows selectivity for EO and conversion of $\mathrm{C}_{2} \mathrm{H}_{4}$ in each cycle of CLE. The sample calcined at $650^{\circ} \mathrm{C}$ was the most selective for EO, giving selectivity for $\mathrm{EO}>55 \%$ at $\sim 9 \%$ conversion of $\mathrm{C}_{2} \mathrm{H}_{4}$, and no drop in performance was observed upon cycling. For comparison, selectivities in the direct epoxidation of $\mathrm{C}_{2} \mathrm{H}_{4}$ with $\mathrm{O}_{2(\mathrm{~g})}$, using clean $\mathrm{Ag}_{\text {g }} \mathrm{Al}_{2} \mathrm{O}_{3}$ range from $25 \%$ to $50 \%$ [22,37]. Notably, the sample calcined at $500^{\circ} \mathrm{C}$, which had the smallest Ag particles, was almost inactive, which means very small amounts of products were detected, thus, the error of that measurement was the highest. Ignoring

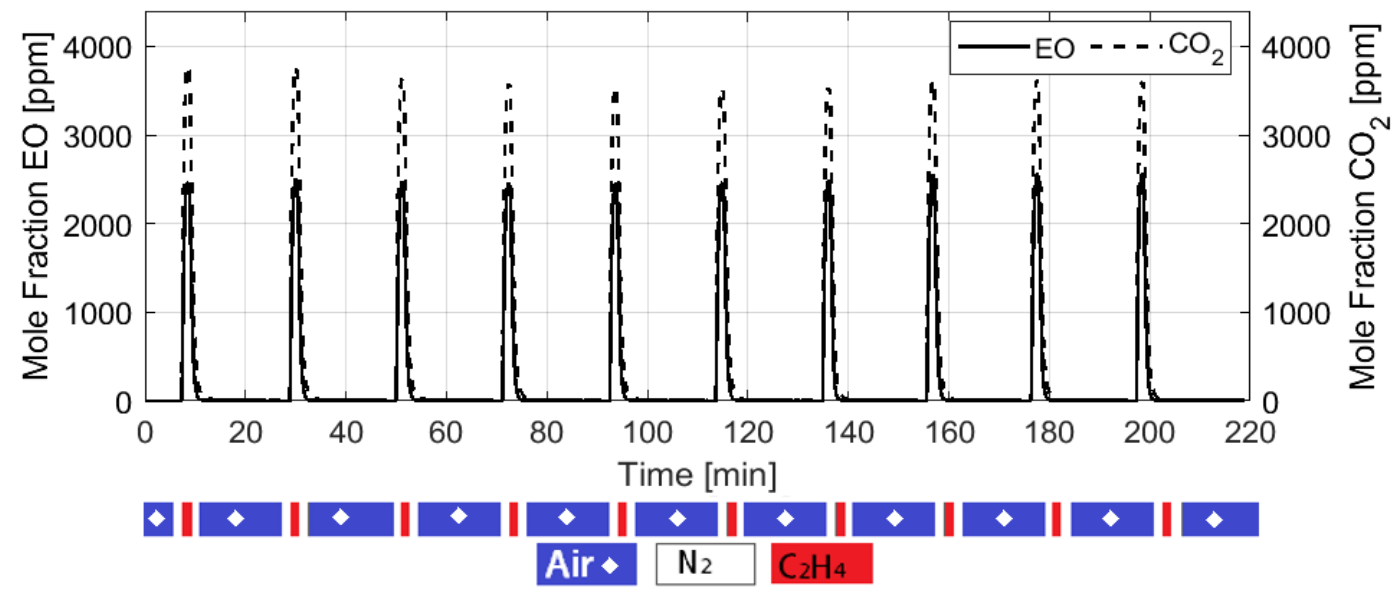

Fig. 9. $\mathrm{EO}$ and $\mathrm{CO}_{2}$ profiles collected during a chemical looping epoxidation experiment carried out in a packed bed with a $2 \mathrm{~g}$ of $15 \mathrm{wt} \% \mathrm{Ag} / \mathrm{SrFeO}_{3}$, calcined at $650^{\circ} \mathrm{C}$. One cycle consisted of: i) 2 min purge with $\mathrm{N}_{2}$, ii) 1.5 min reduction in 5.16 vol\% $\mathrm{C}_{2} \mathrm{H}_{4}$ (in $\mathrm{N}_{2}$ ), iii) 2 min purge of $\mathrm{N}_{2}$, iv) 15 min reoxidation in air. Colour labels: blue $=$ Air, white $=\mathrm{N}_{2}$, red $=\mathrm{C}_{2} \mathrm{H}_{4}$. $T=270^{\circ} \mathrm{C}, p=1 \mathrm{~atm}$. 



Fig. 10. Selectivity for $\mathrm{EO}$ and conversion of $\mathrm{C}_{2} \mathrm{H}_{4}$ for $15 \mathrm{wt} \% \mathrm{Ag} / \mathrm{SrFeO} \mathrm{O}_{3}$ samples calcined at temperatures ranging from $500^{\circ} \mathrm{C}$ to $700^{\circ} \mathrm{C}$. CLE experiments were performed 7 days after calcination for all samples.

the $500^{\circ} \mathrm{C}$ sample from the selectivity graph, we can conclude that the selectivity in CL increased when the sample was calcined at a higher temperature, except for the sample calcined at $700^{\circ} \mathrm{C}$. As shown in Table 1, the sample prepared at $700^{\circ} \mathrm{C}$ had smaller $\mathrm{Ag}$ particles, similar to the sample calcined at $550^{\circ} \mathrm{C}$. Selectivity for EO of these two samples was close, indicating dependence on the size of Ag. On the other hand, the results for the conversion of $\mathrm{C}_{2} \mathrm{H}_{4}$ clearly connected to the temperature of calcination.

Samples other than the one calcined at $650^{\circ} \mathrm{C}$ were less stable with CLE cycles, exhibiting a maximum in selectivity for EO in the first cycle, followed by a significant drop when the experiment progressed. Conversion of $\mathrm{C}_{2} \mathrm{H}_{4}$ noticeably decayed only for two samples, calcined at 550 and $700^{\circ} \mathrm{C}$, indicating some degree of deactivation (Fig. 10). For the rest of the samples, the conversion values were stable, meaning the overall samples' activities remained at similar levels. Hence, the drop in selectivity was, at least to some degree, decoupled from the sample's activity, differentiating CLE from classical non-stoichiometric epoxidation with $\mathrm{O}_{2(\mathrm{~g})}$ [38]. This is in contrast with the results from the previous study on CLE, which showed that the drop in selectivity correlated with the sample's activity [7]. The authors were able to increase both parameters with prolonged reoxidation of the oxygen carrier, $\mathrm{SrFeO}_{3}$ [7]. Yet, despite doubling the reoxidation time both selectivity and conversion for $\mathrm{C}_{2} \mathrm{H}_{4}$, were still decaying in cycling. The sample analysed by Chan et al. was also $15 \% \mathrm{Ag} / \mathrm{SrFeO}_{3}$, calcined at $500^{\circ} \mathrm{C}$, and it performed poorly in epoxidation, similar to the analogues sample used here (Fig. 10). 
While Chan et al. showed that the time of reoxidation influenced the performance for the sample calcined at $500^{\circ} \mathrm{C}$, the results in Fig. 10 for samples calcined at higher temperatures evidence the 15 min reoxidation was sufficient to maintain material's activity. This is supported by the TGA results in Fig. 4, which shows that samples calcined at 600 and $650^{\circ} \mathrm{C}$ reoxidised much faster than the samples prepared at 500 and $550^{\circ} \mathrm{C}$. Although the TGA experiments indicate that neither sample reoxidised fully, the ratio of oxidation/reduction time in the TGA was 8/3, much less than 10 in the packed bed experiments, thus, the full reduction was not expected.

Oxygen carriers should maintain similar activity as long as their oxygen reservoir is not severely depleted even if it is overall reduced after each cycle. This will be true only if the net change in oxygen capacity of $\mathrm{SrFeO}_{3}$ in $10 \mathrm{CLE}$ cycles was small, otherwise, the reduction of $\mathrm{SrFeO}_{3}$ should change with conversion [39]. Here, in each cycle, $\mathrm{SrFeO}_{3}$ lost up to $5 \%$ of its oxygen capacity (taking $\mathrm{SrFeO}_{2.5}$ as the final stoichiometry, although $\mathrm{SrFeO}_{3}$ can reduce further, to $\mathrm{SrO}$ and $\mathrm{Fe}$ [11]). It might be that the drop in performance will be visible over hundreds of cycles rather than 10 cycles shown here, but then, mechanical, thermal and chemical stresses within the catalyst and oxygen carrier may as well be responsible for the change in the CLE performance.
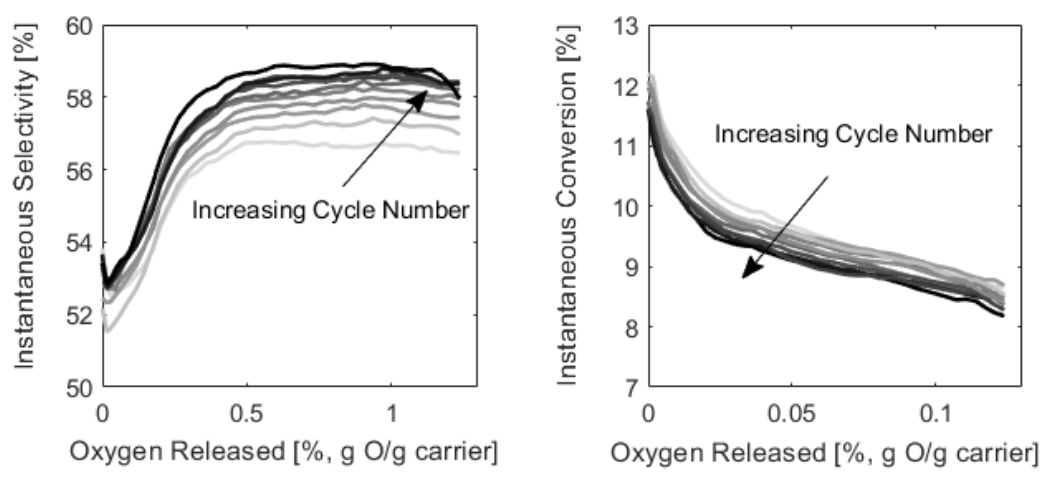

Fig. 11. Comparison of the instantaneous selectivity for EO (left) and conversion of $\mathrm{C}_{2} \mathrm{H}_{4}$ (right) in CLE for $15 \mathrm{wt} \%$ $\mathrm{Ag} / \mathrm{SrFeO}$ calcined at $650^{\circ} \mathrm{C}$ (left). The change in colour indicates the increasing cycle number.

Instantaneous selectivities and conversions measured during $1.5 \mathrm{~min}$ of epoxidation in the function of oxygen release for the stably performing sample calcined at $650^{\circ} \mathrm{C}$ are presented in Fig. 11 . Repeatedly in each cycle, when $\mathrm{SrFeO}_{3}$ released oxygen, the conversion of $\mathrm{C}_{2} \mathrm{H}_{4}$ decreased slightly, but at the same time, the selectivity for EO was almost constant. Results in Fig. 11 corroborate with the conclusion that the rate of reduction of $\mathrm{SrFeO}_{3}$ changes slightly with conversion $(\delta)$. For samples that 


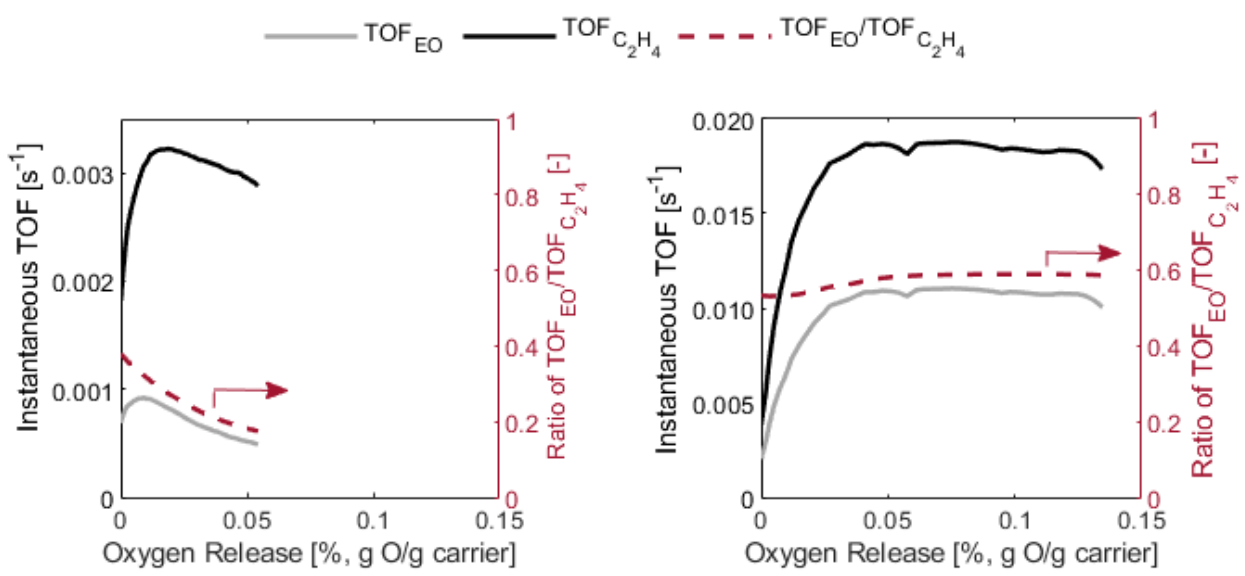

Fig. 12. Turnover frequencies (TOF) for $\mathrm{EO}$ and $\mathrm{C}_{2} \mathrm{H}_{4}$ in the $10^{\text {th }}$ cycle of $\mathrm{CLE}$ for $15 \mathrm{wt} \% \mathrm{Ag} / \mathrm{SrFeO}$ calcined at $550^{\circ} \mathrm{C}$ (left) and $650^{\circ} \mathrm{C}$ (right) and the ratio between TOFs.

were less selective (calcined at lower temperatures as well as the sample calcined at $700^{\circ} \mathrm{C}$ ), both instantaneous parameters were decaying across each cycle, similarly to the result shown by Chan at el. [7].

A comparison of turnover frequencies (TOF) for $\mathrm{EO}$ and $\mathrm{C}_{2} \mathrm{H}_{4}$ in the last cycle of CLE is shown in Fig. 12, while average values for TOFs are given in Table 3. Notably, the sample calcined at $650^{\circ} \mathrm{C}$ showed TOF for EO around $10 x$ higher than the sample calcined at $550^{\circ} \mathrm{C}$. Clearly, the delivery of oxygen in the sample calcined at $650^{\circ} \mathrm{C}$ was significantly higher, allowing for faster reaction.

Table 3. Oxygen release and turnover frequencies for $\mathrm{EO}$ and $\mathrm{C}_{2} \mathrm{H}_{4}$ from $10^{\text {th }} \mathrm{CLE}$ cycle performed in a packed bed reactor. TOF values correspond to maxima exhibited within the cycle.

\begin{tabular}{|c|c|c|c|c|}
\hline Sample & Oxygen released & $\frac{0_{\text {released }}}{\text { Surface }_{\mathrm{Ag}}}$ & TOF $_{\mathrm{C} 2 \mathrm{H} 4}$ & TOF $_{\mathrm{EO}}$ \\
\hline & {$\left[\times 10^{-4} \mathrm{~mol} \mathrm{O} \mathrm{g}^{-1}\right]$} & {$[-]$} & {$\left[\times 10^{-2} \mathrm{~s}^{-1}\right]$} & {$\left[\times 10^{-2} \mathrm{~s}^{-1}\right]$} \\
\hline $500^{\circ} \mathrm{C} 15 w t \% \mathrm{Ag} / \mathrm{SrFeO}_{3}$ & 0.06 & 0.21 & 0.06 & 0.02 \\
\hline $550^{\circ} \mathrm{C} 15 w t \% \mathrm{Ag} / \mathrm{SrFeO}_{3}$ & 0.34 & 1.31 & 0.32 & 0.09 \\
\hline $600^{\circ} \mathrm{C} 15 w t \% \mathrm{Ag} / \mathrm{SrFeO}_{3}$ & 0.66 & 3.36 & 0.94 & 0.38 \\
\hline $650^{\circ} \mathrm{C} 15 w t \% \mathrm{Ag} / \mathrm{SrFeO}_{3}$ & 0.84 & 5.15 & 1.87 & 1.10 \\
\hline
\end{tabular}



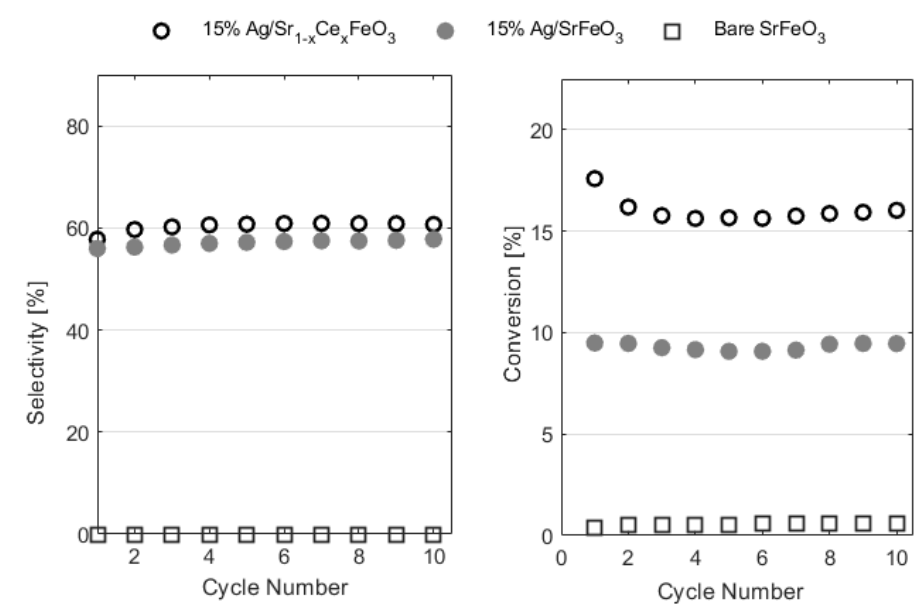

Fig. 13. Selectivity for $\mathrm{EO}$ and conversion of $\mathrm{C}_{2} \mathrm{H}_{4}$ for $15 \mathrm{wt} \% \mathrm{Ag} / \mathrm{Sr}_{1-\mathrm{x}} \mathrm{Ce}_{\mathrm{x}} \mathrm{FeO}_{3}, 15 \mathrm{wt} \% \mathrm{Ag} / \mathrm{SrFeO} \mathrm{O}_{3}$ and bare $\mathrm{SrFeO}_{3}$ calcined at $650^{\circ} \mathrm{C}$. CLE experiment was performed 7 days after calcination.

\section{CLE for $\mathrm{Ag} / \mathrm{Sr}_{1-\mathrm{x}} \mathrm{Ce}_{\mathrm{x}} \mathrm{FeO}_{3}$ calcined at $650^{\circ} \mathrm{C}$}

Results from a CLE experiment using $15 \mathrm{wt} \% \mathrm{Ag} / \mathrm{Sr}_{1-x} \mathrm{Ce}_{x} \mathrm{FeO}_{3}$ are presented in Fig. 13. Compared to $\mathrm{Ag} / \mathrm{SrFeO}_{3}$, the Ce-doped oxygen carrier performed better in CLE, with selectivity for $\mathrm{EO}$ and conversion for $\mathrm{C}_{2} \mathrm{H}_{4}$ increasing to $\sim 60 \%$ and $15 \%$, respectively. As argued by Marek et al. [8], good selectivity and stable performance in CLE depends on fast oxygen diffusion in the oxygen carrier. In $\mathrm{Ag} / \mathrm{Sr}_{1-x} \mathrm{Ce}_{x} \mathrm{FeO}_{3}$, faster ionic conduction is attained when $\mathrm{Ce}$ is introduced in small amounts [12]. As a result, the metal oxide can donate more oxygen in CLE, explaining the significantly higher conversions of $\mathrm{C}_{2} \mathrm{H}_{4}$. Overall, $15 \mathrm{wt} \% \mathrm{Ag} / \mathrm{Sr}_{1-x} \mathrm{Ce}_{x} \mathrm{FeO}_{3}$ calcined at $650^{\circ} \mathrm{C}$ is, so far, the best performing sample for CLE reported in the literature.

\section{Effect of storage time on catalyst performance}

Samples of $\mathrm{SrFeO}_{3}$ after impregnation with $15 \mathrm{wt} \% \mathrm{Ag}$, were used in packed bed CLE experiments waiting 7 days or $>60$ days from the day of calcination. Results for $15 \mathrm{wt} \% \mathrm{Ag} / \mathrm{SrFeO}_{3}$ calcined at $650^{\circ} \mathrm{C}$ are presented in Fig. 14. For the rest of the samples, the influence of sample storage was similar and is shown in Figs. S9 and S10 in the Supplementary Information. Accumulation of impurities leads to higher production of $\mathrm{CO}_{2}$, resulting in a lower selectivity for $\mathrm{EO}$ and higher conversion of $\mathrm{C}_{2} \mathrm{H}_{4}$. This increased level of $\mathrm{CO}_{2}$ did not originate from the decomposition of carbonates, because the carbon balance in both experiments was $\sim 95 \%$. The presence of impurities was shown detrimental also in classical epoxidation with $\mathrm{O}_{2(\mathrm{~g})}$; impurities of acidic nature (hydroxyl groups) lead to subsequent 



Fig. 14. Comparison of selectivity for $\mathrm{EO}$ (left) and conversion for $\mathrm{C}_{2} \mathrm{H}_{4}$ (right) in CLE experiments for $15 \mathrm{wt} \% \mathrm{Ag} / \mathrm{SrFeO}_{3}$ calcined at $650^{\circ} \mathrm{C}$, for fresh ( $t=7$ days) and old ( $t>60$ days) samples.

combusting of EO [40], while the presence of carbonates to blocking of Ag surface [22]. Carbonates also impair $\mathrm{SrFeO}_{3}$, hindering its oxygen permeability [41]. Therefore, the more impurities are present, the less active and selective catalyst is expected. While this might be a part of the story seen in Fig. 14, because selectivity for EO of the stored sample did drop, the increase in conversion of $\mathrm{C}_{2} \mathrm{H}_{4}$ suggests that the acidic surface in CLE promoted direct combustion of $\mathrm{C}_{2} \mathrm{H}_{4}$.

As seen in the TGA experiments (Fig. 7), about 50\% of surface impurities accumulated in the $\mathrm{Ag} / \mathrm{SrFeO}_{3}$ sample calcined at $650^{\circ} \mathrm{C}$ was removed upon heating to $270^{\circ} \mathrm{C}$. The thermally induced removal of carbonates and hydroxides was also evidenced by measuring $\mathrm{CO}_{2}$ and $\mathrm{H}_{2} \mathrm{O}$ in the off-gas from the packed bed when the sample was heated up for the CLE experiment (Fig. S11). Because impurities are not stable at elevated temperatures, the accumulation of new impurities during CLE is not expected. Nevertheless, dedicated research with long cycling is needed for confirmation.

The removal of impurities was investigated by repeating the last thermal treatment (calcination for depositing $\mathrm{Ag}$ ) and running a CLE experiment. The recalcined sample showed good performance only in the first cycles, similarly to the ex-situ regenerated samples in our previous study [7]. Therefore, the temperature treatment needs optimising to effectively purify the surface of $\mathrm{Ag} / \mathrm{SrFeO}_{3}$. Alternatively, CLE should be performed shortly after depositing $\mathrm{Ag}$ on $\mathrm{SrFeO}_{3}$. As shown in Fig. S5, freshly calcined samples result in repeatable performance in CLE. Finally, $\mathrm{SrFeO}_{3}$ can be manipulated to prevent the accumulation of impurities, for example, by doping the B-site with high-valent elements, such as $\mathrm{Ti}$, $\mathrm{Zr}, \mathrm{Nb}$, and Ta. This prevents interactions with $\mathrm{CO}_{2}$ [29] but can lead to a more acidic perovskite. 


\section{Discussion}

Figure 15 presents the results from CLE experiments as a function of Ag size. The distribution of silver is crucial in epoxidation because the size of $\mathrm{Ag}$ particles influences the selectivity of the reaction. In classical epoxidation with $\mathrm{O}_{2(\mathrm{~g})}$, nano-sized particles of $\mathrm{Ag}$ promote secondary oxidation of ethylene oxide [22]. Here, the smallest particles turned out to be almost inactive, and the conversion of $\mathrm{C}_{2} \mathrm{H}_{4}$ was the same as for bare $\mathrm{SrFeO}_{3}$ (which combusted $\mathrm{C}_{2} \mathrm{H}_{4}$ giving $~ 500$ ppm of $\mathrm{CO}_{2}$ ). With the temperature of calcination, the size of the Ag particles increased, except for the sample prepared at $700^{\circ} \mathrm{C}$. For the two discussed performance parameters, Fig. 15 shows that selectivity for EO in CLE depended primarily on the size of Ag particles, while conversion for $\mathrm{C}_{2} \mathrm{H}_{4}$, on the temperature applied during impregnation with $\mathrm{Ag}$. In fact, the first parameter changed linearly with $D_{A g}\left(\mathrm{R}^{2}=0.97\right)$, while the latter increased linearly with the calcination temperature $\left(\mathrm{R}^{2}=0.98\right)$. The dependency of selectivity to EO on the size of Ag aligns with multiple observations made in classical epoxidation with $\mathrm{O}_{2(\mathrm{~g})}($ e.g., $[38,42])$, where selectivity increases until an optimal size of $\mathrm{Ag}$ is reached. The mechanism behind this variation is reasonably well explained, and involves more oxidic nature of $\mathrm{Ag}$ nanoparticles [22]. The dependency reported here with respect to the conversion of $\mathrm{C}_{2} \mathrm{H}_{4}$ is most likely characteristic only for CLE, for instance, if the material's activity depends on the $\mathrm{Ag}-\mathrm{SrFeO}_{3}$ interface, which changes with the applied thermal treatment. Clearly, the conversion of $\mathrm{C}_{2} \mathrm{H}_{4}$ did not rely on the extent of this $\mathrm{Ag}-\mathrm{SrFeO}_{3}$ interface (for the supporting argument, see Section 9 in the Supporting Information).

It is clear from Table 1 and Fig. 15 that a higher $n_{s}$, number of moles of surface Ag atoms, did not lead to a higher conversion nor higher selectivity. If $n_{s}$ correlates directly with the number of active Ag
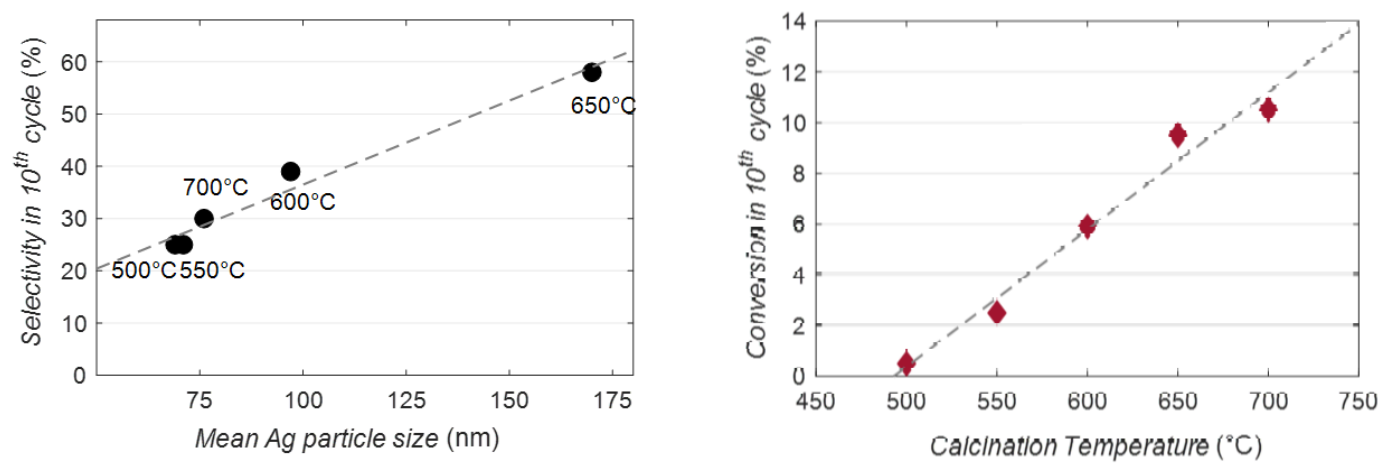

Fig. 15. Selectivity for $\mathrm{EO}$ as a function of $\mathrm{Ag}$ size (left) and conversion of $\mathrm{C}_{2} \mathrm{H}_{4}$ as a function of the calcination temperature (right). Dashed lines indicate linear fit. 
sites, the latter was not crucial for good performance in CLE. It seems that even if more active sites were present in smaller Ag particles, oxygen was not efficiently delivered to them. Alternatively, the number of active $\mathrm{Ag}$ sites did not align directly with $n_{s}$, for example if some specific type of surface $\mathrm{Ag}$ atoms was inactive.

Previous studies on epoxidation linked selectivity for EO with a higher degree of surface oxygen electrophilicity [4], which can be defined as the ratio of electrophilic to nucleophilic oxygen adsorbed on the surface $\left(\mathrm{O}_{\mathrm{a}}\right)$. The degree of electrophilicity is a function of the amount of subsurface oxygen $\left(\mathrm{O}_{\mathrm{ss}}\right)$ dissolved in Ag. $\mathrm{O}_{\mathrm{ss}}$ withdraws the surface charge and renders the surface more electrophilic [43]. Accordingly, high accumulation of subsurface oxygen will result in a more selective process. In CLE, where oxygen is most likely delivered to $\mathrm{Ag}$ via the $\mathrm{Ag}-\mathrm{SrFeO}_{3}$ interface [7], larger $\mathrm{Ag}$ particles can accumulate more $\mathrm{O}_{\text {dissolved }}$ and less $\mathrm{O}_{\mathrm{a}}$ than smaller Ag particles. In case of charge transfer towards the bulk of $\mathrm{Ag}$, this might explain why in CLE the size of $\mathrm{Ag}$ correlates with selectivity for EO.

The size of Ag particles is likely not the only factor determining the final selectivity. CLE is similar to electrochemical epoxidation in the sense that both processes involve $\mathrm{O}_{\text {lattice. }}$ In the mechanism explaining oxygen transport for electrochemical epoxidation [44] and CLE [7], $\mathrm{O}_{\text {lattice }}$ transforms firstly to $\mathrm{O}_{\text {dissolved }}$ and then to $\mathrm{O}_{\mathrm{ss}}$ and $\mathrm{O}_{\mathrm{a}}$. Thus, the degree of electrophilicity of an $\mathrm{Ag}$ surface might be limited by the oxygen flux across the $\mathrm{Ag}-\mathrm{SrFeO}_{3}$ interface. The results in Fig. 11, show that the selectivity for EO was stable throughout the CLE cycles for the sample calcined at $650^{\circ} \mathrm{C}$; therefore, the degree of electrophilicity was maintained. This was not the case for samples calcined at lower temperatures, where selectivity for EO decayed; in these samples, the oxygen transfer might be hindered by slow $\mathrm{O}_{\text {lattice }}-\mathrm{O}_{\text {ss }}$ transformation. For the sample calcined at $700^{\circ} \mathrm{C}$, the rate of oxygen delivery was the fastest, but the Ag particles were small, and that combination still led to low selectivity. Furthermore, the reactivity of that sample quickly decayed (Fig. 10), which can be explained by the depletion of $\mathrm{SrFeO}_{3}$ from oxygen (larger $\delta$ ).

Enhanced oxygen delivery, even at high $\delta$, was observed previously in CLE, but only when the oxygen carrier, $\mathrm{SrFeO}_{3}$, was mixed with $\mathrm{CeO}_{2}$ [8]. Combining both effects here, the advantage of large $\mathrm{O}_{\text {lattice }}$ flux across the $\mathrm{Ag}-\mathrm{SrFeO}_{3}$ interface and maintained oxygen donation even at a high $\delta$, was 
observed in the sample doped with $\mathrm{Ce}$ and calcined at $650^{\circ} \mathrm{C}$. In $\mathrm{Sr}_{1-x} \mathrm{Ce}_{x} \mathrm{FeO}_{3}, \mathrm{Ce}$ helped with the ionic transport within the perovskite [12], allowing for high activity despite depletion from oxygen. As a result, the conversion for $\mathrm{C}_{2} \mathrm{H} 4$ in the $\mathrm{Sr}_{1-x} \mathrm{Ce}_{x} \mathrm{FeO}_{3}$ sample increased to $15 \%$ (in comparison to $10 \%$ obtained in [8] for a $\mathrm{CeO}_{2}$-doped perovskite), while the selectivity for $\mathrm{EO}$ remained at a high, $60 \%$ level.

The results presented in this study demonstrate that $\mathrm{Ag}$ needs to be firmly set onto $\mathrm{SrFeO}_{3}$, and that the interface between $\mathrm{Ag}$ and $\mathrm{SrFeO}_{3}$ is of crucial importance. Similar observations were noticed in electrocatalytic oxygen reduction studies, in which Ag was used as a cathode. Transition 3d-metals from solid electrolytes interact strongly with Ag. As a result, the charge is transferred from the 3-d metal to Ag via the ligand effect [30], as observed with EELS results (Fig. 5) and indicated with $\mathrm{H}_{2-}$ TPR (Fig. 8). This, in turn, strengthens the adsorption of oxygen species [45], and, thus, directly affects the reduction and reoxidation of the $\mathrm{Ag}-\mathrm{SrFeO}_{3}$ composite. One would expect that upon epoxidation, the charge transfer has a similar influence on the Ag surface electrophilicity as the accumulation of $\mathrm{O}_{\mathrm{ss}}$, again, promoting higher selectivity on larger $\mathrm{Ag}$ particles. Another mechanism at the $\mathrm{Ag}-\mathrm{SrFeO}_{3}$ interface that can play a role involves the strain mismatch between the crystal structures of the deposited metal particles and the perovskite. While strain between two phases can be easily affected by the calcination temperature and methodology of sample preparation [46], the influence of strain is believed to be small for large, $>20 \mathrm{~nm}$, particles [30].

The presented results suggest that the charge transfer from Fe to Ag might be responsible for higher EO selectivity on larger Ag particles. Practical conclusions emerge, that higher temperature in calcination promotes better interaction between $\mathrm{Ag}$ and $\mathrm{SrFeO}_{3}$ and results in faster oxygen release and uptake. Clearly, both are crucial for maintaining stable CLE performance. The proposed variations in the thermal treatment of the $\mathrm{Ag} / \mathrm{SrFeO}_{3}$ catalyst provide a simple optimisation method for CLE of improved performance. Another practical conclusion involves the accumulation of $\mathrm{Ag} / \mathrm{SrFeO}{ }_{3}$ surface impurities, which are detrimental in CLE performance. While thermal treatment is an easy option for removing carbonates and hydroxides, activating stored CLE catalysts is needed. 


\section{Conclusions}

The experiments showed that the addition of $\mathrm{Ag}$ to the surface of $\mathrm{SrFeO}_{3}$ influenced its redox properties, catalysing oxygen release and uptake. Consequently, selectivity for EO in epoxidation via chemical looping route increased with the size of Ag particles deposited on oxygen carrier, $\mathrm{SrFeO}_{3}$. Conversion of $\mathrm{C}_{2} \mathrm{H}_{4}$, on the other hand, increased with the temperature of sample calcination. Thus, selectivity was decoupled from the sample's activity, which differentiates CLE from classical epoxidation with $\mathrm{O}_{2(\mathrm{~g})}$. The presented EELS results indicate that the thermal treatment in calcination cemented the interface between silver and $\mathrm{SrFeO}_{3}$, resulting in the charge transfer, which helped with faster delivery of oxygen to the place of reaction. In consequence, high selectivity for EO and high conversion of $\mathrm{C}_{2} \mathrm{H}_{4}$ were attained simultaneously. Gaining from these findings, a superior CLE performance in terms of selectivity for $\mathrm{EO}(60 \%)$, conversion of $\mathrm{C}_{2} \mathrm{H}_{4}(15 \%)$, and stability during redox cycling was obtained with $\mathrm{Ag} / \mathrm{Sr}_{1-x} \mathrm{Ce}_{x} \mathrm{FeO}_{3}$. Finally, $\mathrm{H}_{2}$-TPR results confirmed the O-species participating in the reaction can be attributed to the removal of the first monolayer of oxygen in $\mathrm{SrFeO}_{3}$.

\section{Acknowledgements}

The authors thank Dr Stuart Scott for helpful discussions and access to the experimental facilities (TGA, packed bed reactor). Dr Heather F. Greer is acknowledged for helping with the TEM and EELS analysis and helpful discussions about the structure of our samples. Joseph El-Kadi and Colin Smith are acknowledged for helping with the $\mathrm{H}_{2}$-TPR experiments and analysis.

\section{References}

[1] C.H. McAteer, R. Murugan, Y.V. Subba Rao, Heterogeneously catalyzed synthesis of heterocyclic compounds, Adv. Heterocycl. Chem. 121 (2017) 173-205. https://doi.org/10.1016/bs.aihch.2016.03.003.

[2] S.A. Hauser, M. Cokoja, F.E. Kühn, Epoxidation of olefins with homogeneous catalysts - quo vadis?, Catal. Sci. Technol. 3 (2013) 552-561. https://doi.org/10.1039/C2CY20595E.

[3] S. Rebsdat, D. Mayer, Ethylene Oxide, in: Ullmanns Encycl. Ind. Chem., American Cancer Society, 2001. https://doi.org/10.1002/14356007.a10_117.

[4] M.O. Özbek, R.A. van Santen, The Mechanism of Ethylene Epoxidation Catalysis, Catal. Lett. 143 (2013) 131-141. https://doi.org/10.1007/s10562-012-0957-3.

[5] S.A. Miller, Ethylene and its industrial derivatives, Benn, 1969.

[6] S. Aryana, M. Ahmadi, V.G. Gomes, J.A. Romagnoli, K. Ngian, Modelling and optimisation of an industrial ethylene oxide reactor, Chem. Prod. Process Model. 4 (2009). https://doi.org/10.2202/1934-2659.1231.

[7] M.S.C. Chan, E. Marek, S.A. Scott, J.S. Dennis, Chemical looping epoxidation, J. Catal. 359 (2018) 1-7. https://doi.org/10.1016/j.jcat.2017.12.030. 
[8] E.J. Marek, S. Gabra, J.S. Dennis, S.A. Scott, High selectivity epoxidation of ethylene in chemical $\begin{array}{lllllll}\text { looping setup, Appl. Catal. B Environ. } 262 & \text { (2020) } & 118216 .\end{array}$ https://doi.org/10.1016/j.apcatb.2019.118216.

[9] X. Zhu, Q. Imtiaz, F. Donat, C.R. Müller, F. Li, Chemical looping beyond combustion - a perspective, Energy Environ. Sci. (2020). https://doi.org/10.1039/C9EE03793D.

[10] F. Solymosi, The bonding, structure and reactions of $\mathrm{CO}_{2}$ adsorbed on clean and promoted metal surfaces, J. Mol. Catal. 65 (1991) 337-358. https://doi.org/10.1016/0304-5102(91)85070-I.

[11] E. Marek, W. Hu, M. Gaultois, C.P. Grey, S.A. Scott, The use of strontium ferrite in chemical looping systems, Appl. Energy. $223 \quad$ (2018) 369-382. https://doi.org/10.1016/j.apenergy.2018.04.090.

[12] F. Deganello, L.F. Liotta, A. Longo, M.P. Casaletto, M. Scopelliti, Cerium effect on the phase structure, phase stability and redox properties of Ce-doped strontium ferrates, J. Solid State Chem. 179 (2006) 3406-3419. https://doi.org/10.1016/j.jssc.2006.06.027.

[13] L. Lutterotti, H. Wenk, S. Matthies, MAUD (Material Analysis Using Diffraction): a user friendly Java program for Rietveld Texture Analysis and more, in: NRC Research Press, 1999: pp. 15991604. https://iris.unitn.it/handle/11572/57067 (accessed May 10, 2020).

[14] J.P. Hodges, S. Short, J.D. Jorgensen, X. Xiong, B. Dabrowski, S.M. Mini, C.W. Kimball, Kimball, Evolution of oxygen-vacancy ordered crystal structures in the perovskite series SrnFenO3n-1 $(n=2,4,8$, and $\infty)$, and the relationship to electronic and magnetic properties, J. Solid State Chem. 151 (2000) 190-209. https://doi.org/10.1006/jssc.1999.8640.

[15] G. Becherer, R. Ifland, Über eine Präzisionsbestimmung der Gitterkonstanten von Silber nach dem Rückstrahlverfahren, Naturwissenschaften. $41 \quad$ (1954) 471-471. https://doi.org/10.1007/BF00628793.

[16] C.A. Schneider, W.S. Rasband, K.W. Eliceiri, NIH Image to ImageJ: 25 years of image analysis, Nat. Methods. 9 (2012) 671-675. https://doi.org/10.1038/nmeth.2089.

[17] X.E. Verykios, F.P. Stein, R.W. Coughlin, R.W. Coughlin, Influence of metal crystallite size and morphology on selectivity and activity of ethylene oxidation catalyzed by supported silver, J. Catal. 66 (1980) 368-382. https://doi.org/10.1016/0021-9517(80)90040-8.

[18] X.G. Zhou, W.K. Yuan, Modeling silver catalyst sintering and epoxidation selectivity evolution in ethylene oxidation, Chem. Eng. Sci. 59 (2004) 1723-1731. https://doi.org/10.1016/j.ces.2004.01.028.

[19] J. Li, Z. Wang, Y. Li, F.L. Deepak, In-situ atomic-scale observation of kinetic pathways of sublimation in silver nanoparticles, Adv. Sci. $6 \quad$ (2019) 1802131. https://doi.org/10.1002/advs.201802131.

[20] S.N. Goncharova, E.A. Paukshtis, B.S. Bal'zhinimaev, Size effects in ethylene oxidation on silver catalysts. Influence of support and Cs promoter, Appl. Catal. Gen. 126 (1995) 67-84. https://doi.org/10.1016/0926-860X(95)00036-4.

[21] N. Macleod, J.M. Keel, R.M. Lambert, The effects of catalyst aging under industrial conditions: Ethylene oxide conversion over Ag-Cs $/ \alpha-\mathrm{Al}_{2} \mathrm{O}_{3}$ catalysts, Catal. Lett. 86 (2003) 51-56. https://doi.org/10.1023/A:1022602807322.

[22] V.I. Bukhtiyarov, A. Knop-Gericke, Ethylene Epoxidation over Silver Catalysts (Chapter 9), in: Nanostructured Catal., 2011: pp. 214-247. https://doi.org/10.1039/9781847559876-00214.

[23] L.A. McNeil, G.A. Mutch, F. Iacoviello, J.J. Bailey, G. Triantafyllou, D. Neagu, T.S. Miller, E.I. Papaioannou, W. Hu, D.J.L. Brett, P.R. Shearing, I.S. Metcalfe, Dendritic silver self-assembly in molten-carbonate membranes for efficient carbon dioxide capture, Energy Environ. Sci. (2020). https://doi.org/10.1039/C9EE03497H.

[24] M. Camaratta, E. Wachsman, Silver-bismuth oxide cathodes for IT-SOFCs; Part I Microstructural instability, Solid State Ion. 178 (2007) 1242-1247. https://doi.org/10.1016/j.ssi.2007.06.009.

[25] M. Mosiałek, E. Bielańska, R.P. Socha, M. Dudek, G. Mordarski, P. Nowak, J. Barbasz, A. Rapacz-Kmita, Changes in the morphology and the composition of the Ag|YSZ and Ag|LSM interfaces caused by polarization, Solid State Ion. 225 (2012) 755-759. https://doi.org/10.1016/j.ssi.2012.03.011.

[26] A.J. Majewski, A. Dhir, Application of silver in microtubular solid oxide fuel cells, Mater. Renew. Sustain. Energy. 7 (2018) 16. https://doi.org/10.1007/s40243-018-0123-y. 
[27] K. Beppu, S. Hosokawa, T. Shibano, A. Demizu, K. Kato, K. Wada, H. Asakura, K. Teramura, T. Tanaka, Enhanced oxygen-release/storage properties of Pd-loaded Sr3Fe2O7- $\delta$, Phys. Chem. Chem. Phys. 19 (2017) 14107-14113. https://doi.org/10.1039/C7CP01614J.

[28] A. Feldhoff, J. Martynczuk, M. Arnold, M. Myndyk, I. Bergmann, V. Šepelák, W. Gruner, U. Vogt, A. Hähnel, J. Woltersdorf, Spin-state transition of iron in $\left(\mathrm{Ba}_{0.5} \mathrm{Sr}_{0.5}\right)\left(\mathrm{Fe}_{0.8} \mathrm{Zn}_{0.2}\right) \mathrm{O}_{3-\delta}$ perovskite, J. Solid State Chem. 182 (2009) 2961-2971. https://doi.org/10.1016/j.jssc.2009.07.058.

[29] Y.L. Xing, B. Park, Z. Wang, K.T. Kang, J. Seo, J.C. Kim, H.Y. Jeong, W.S. Choi, S.H. Oh, In situ Negative Cs HRTEM Imaging of Topotactic Phase Transformation from Perovskite $\mathrm{SrFeO}_{3}$ to Brownmillerite $\mathrm{SrFeO}_{2.5}$, Microsc. Microanal. $25 \quad$ (2019) 1482-1483. https://doi.org/10.1017/S1431927619008146.

[30] S.-A. Park, E.-K. Lee, H. Song, Y.-T. Kim, Bifunctional enhancement of oxygen reduction reaction activity on $\mathrm{Ag}$ catalysts due to water activation on $\mathrm{LaMnO} 3$ supports in alkaline media, Sci. Rep. 5 (2015). https://doi.org/10.1038/srep13552.

[31] I. Schmidt, E. Zolotoyabko, K. Lee, A. Gjardy, A. Berner, E. Lakin, P. Fratzl, W. Wagermaier, Effect of strontium ions on crystallization of amorphous calcium carbonate, Cryst. Res. Technol. 54 (2019) 1900002. https://doi.org/10.1002/crat.201900002.

[32] R. Dinescu, M. Preda, Thermal decomposition of strontium hydroxide, J. Therm. Anal. 5 (1973) 465-473. https://doi.org/10.1007/BF01950236.

[33] G.V. Mamontov, V.V. Dutov, V.I. Sobolev, O.V. Vodyankina, Effect of transition metal oxide additives on the activity of an $\mathrm{Ag} / \mathrm{SiO}_{2}$ catalyst in carbon monoxide oxidation, Kinet. Catal. 54 (2013) 487-491. https://doi.org/10.1134/S0023158413040137.

[34] L. Gang, B.G. Anderson, J. van Grondelle, R.A. van Santen, Low temperature selective oxidation of ammonia to nitrogen on silver-based catalysts, Appl. Catal. B Environ. 40 (2003) 101-110. https://doi.org/10.1016/S0926-3373(02)00129-7.

[35] L.A. Isupova, I.S. Yakovleva, G.M. Alikina, V.A. Rogov, V.A. Sadykov, Reactivity of La ${ }_{x} \mathrm{Sr}_{\mathrm{x}} \mathrm{FeO}_{3}-\mathrm{y}(\mathrm{x}=0-1)$ Perovskites in Oxidation Reactions, Kinet. Catal. 46 (2005) 729-735. https://doi.org/10.1007/s10975-005-0129-1.

[36] H. Falcón, J.A. Barbero, J.A. Alonso, M.J. Martínez-Lope, J.L.G. Fierro, $\mathrm{SrFeO}_{3-\delta}$ Perovskite Oxides: Chemical Features and Performance for Methane Combustion, Chem. Mater. 14 (2002) 2325-2333. https://doi.org/10.1021/cm0112921.

[37] R.A. Van Santen, H.P.C.E. Kuipers, The Mechanism of Ethylene Epoxidation, in: D.D. Eley, H. Pines, P.B. Weisz (Eds.), Adv. Catal., Academic Press, 1987: pp. 265-321. https://doi.org/10.1016/S0360-0564(08)60095-4.

[38] J.E. van den Reijen, S. Kanungo, T.A.J. Welling, M. Versluijs-Helder, T.A. Nijhuis, K.P. de Jong, P.E. de Jongh, Preparation and particle size effects of $\mathrm{Ag} / \alpha-\mathrm{Al} 2 \mathrm{O} 3$ catalysts for ethylene epoxidation, J. Catal. 356 (2017) 65-74. https://doi.org/10.1016/j.jcat.2017.10.001.

[39] R.H. Görke, E.J. Marek, F. Donat, S.A. Scott, Reduction and oxidation behavior of strontium perovskites for chemical looping air separation, Int. J. Greenh. Gas Control. 94 (2020) 102891. https://doi.org/10.1016/j.ijggc.2019.102891.

[40] D.A. Bulushev, E.A. Paukshtis, Y.N. Nogin, B.S. Bal'zhinimaev, Transient response and infrared studies of ethylene oxide reactions on silver catalysts and supports, Appl. Catal. Gen. 123 (1995) 301-322. https://doi.org/10.1016/0926-860X(94)00221-5.

[41] Y. Han, J. Yi, X. Guo, Improving the chemical stability of oxygen permeable $\mathrm{SrFeO}-\delta$ perovskite in $\mathrm{CO} 2$ by niobium doping, Solid State Ion. 267 (2014) 44-48. https://doi.org/10.1016/j.ssi.2014.09.009.

[42] A.J.F. van Hoof, E.A.R. Hermans, A.P. van Bavel, H. Friedrich, E.J.M. Hensen, Structure sensitivity of silver-catalyzed ethylene epoxidation, ACS Catal. 9 (2019) 9829-9839. https://doi.org/10.1021/acscatal.9b02720.

[43] M.O. Özbek, I. Önal, R.A. van Santen, Chlorine and caesium promotion of silver ethylene epoxidation catalysts, ChemCatChem. $\quad 5 \quad$ (2013) 443-451. https://doi.org/10.1002/cctc.201200690.

[44] S. Bebelis, C.G. Vayenas, Non-faradaic electrochemical modification of catalytic activity 6. Ethylene epoxidation on Ag deposited on stabilized $\mathrm{ZrO}$, J. Catal. 138 (1992) 588-610. https://doi.org/10.1016/0021-9517(92)90309-6. 
[45] H. Xin, A. Holewinski, N. Schweitzer, E. Nikolla, S. Linic, Electronic structure engineering in heterogeneous catalysis: Identifying novel alloy catalysts based on rapid screening for materials with desired electronic properties, Top. Catal. 55 (2012) 376-390. https://doi.org/10.1007/s11244-012-9794-2.

[46] M. Du, L. Cui, Y. Cao, A.J. Bard, Mechanoelectrochemical catalysis of the effect of elastic strain on a platinum nanofilm for the ORR exerted by a shape memory alloy substrate, J. Am. Chem. Soc. 137 (2015) 7397-7403. https://doi.org/10.1021/jacs.5b03034. 